Jarosław Kurkowski

Warszawa

\title{
Dzieje Rosji w piśmiennictwie doby stanisławowskiej. Część I: do pierwszego rozbioru
}

Piotr Świtkowski w uwagach o piśmiennictwie polskim zamieszczonych w „Pamiętniku Polityczno-Historycznym” z 1785 r. podkreślał (na kanwie głośnych w całej Europie pedagogicznych wskazówek lorda Chesterfielda dla syna), ,że gdy ci, co już z młodych lat wyszli, nie mają wiele czasu do czytania, powinni tylko czytać, co im jest najpotrzebniejszego, jako to historyą i geografię naszego wieku, interessa polityczne monarchów, konstytucyą niniejsza, maxymy, siły, bogactwa, charaktery, partye i kabały dworów europejskich”' Tymczasem „Polak, z przyrodzenia rozsądny i nad wszystkim się zastanawiający, nie ma-li przyczyny na wielką liczbę pism naszych wzruszyć ramion i mówić: cui bono? Jakimiż nas dotąd zarzucano książkami? [...] Żeby odłogiem leżące pole uprawić, zaczynamy od zasiewania na nim kwiatów; chcąc drzewo usychające odżywić, polewamy jego liście, zamiast leczenia korzeni [...] Historia nowa, stan niniejszy krajów, polityka tego wieku, prawa dzisiejsze, ekonomia prywatna i publiczna, bez których naród ostać się nie może, ledwie by były u nas dotąd, gdyby nie Konarski, Wyrwicz, Kluk i Skrzetuski, z naszych książek znane”. Jak można przypuszczać, popularnemu wśród warszawskich elit publicyście i redaktorowi czasopism chodziło tu w pierwszym rzędzie o przemiany polityczne, ekonomiczne, społeczne i administracyjne, które modernizowały osiemnastowieczną Europę i stopniowo przekształciły sąsiadów Rzeczypospolitej w groźne dla jej istnienia główne mocarstwa europejskie oraz wnioski, jakie stąd wynika-

\footnotetext{
1 „Pamiętnik Polityczny i Historyczny”, 1783, t. 1, z. 6 (czerwiec), s. 605.

2 Tamże, s. 603-604. Zob. też W. Smoleński, Przewrót umysłowy w Polsce wieku XVIII. Studia historyczne, oprac. i wstęp A. Wierzbicki, Warszawa 1979, s. 359-360, K. Puchowski, Edukacja historyczna w jezuickich kolegiach Rzeczypospolitej 15651773, Gdańsk 1999, s. 184.
} 
ły dla koniecznej reformy kraju³. Jak zatem naprawdę wygląda dorobek epoki stanisławowskiej w zakresie rosyjskiej historii „,nowej” i dawnej, moskiewskiej polityki „tamtego” i wcześniejszych wieków, ,interessów dworu" już od czasów Piotra I w istotny sposób wpływającego na bieg spraw w polsko-litewskim państwie? Choćby z tego punktu widzenia „wiadomość spraw rossyjskich” powinna być dla naszych elit zadaniem o podstawowym znaczeniu, choć wcale niełatwym do wypełnienia. Rosja, która weszła przebojem do wielkiej polityki europejskiej w poczatkach XVIII stulecia, długo była, zwłaszcza dla autorów zachodnioeuropejskich, obszarem znanym bardzo słabo, utożsamianym raczej z odległa Azją niż z kontynentem europejskim ${ }^{4}$. Wybitny rosyjski historyk XIX w. Siergiej Sołowiow z pewną przesadą podkreślał, iż samo „odkrycie” państwa moskiewskiego to zjawisko paralelne do poznania Ameryki, dzisiejszy badacz amerykański w podobnym tonie dodaje: „It was only during the 16th and 17th centuries that western Europeans «discovered» the lands now known as Russia"5. Aż do początków XVII w. także w Rzeczypospolitej wiedziano niewiele o wschodnim sąsiedzie, niechętnie i z lekceważeniem odnosząc się „do jakiegoś dalekiego państwa, rządzonego bezwzględną tyrania, do ludzi o innej kulturze, innej religii, nie umiejących po łacinie, nie rozumiejących tego, co dla ówczesnej zachodniej i środkowej Europy wraz z Polską było naczelną wartością"6. Trzeba jednak pamiętać, iż kronikarze polscy doby średniowiecza znali najstarsze ruskie kroniki ${ }^{7}$. W początkach XVI w. skapy i bałamutny zasób wiedzy na temat wschodniej części kontynentu przeformowała publikacja Ma-

\footnotetext{
3 Wzorcem propagowanym przez P. Świtkowskiego były rozwiązania brytyjskie (głównie w kwestiach ustrojowych i ekonomicznych). Swoje poglądy na poprawę stanu Rzeczypospolitej przedstawiał często w zawoalowany sposób. I. Homola-Dzikowska, „Pamiętnik Historyczno-Polityczny” Piotra Świtkowskiego 1782-1792, Kraków 1960, s. 141-142, 153-156; R. Butterwick, Stanisław August a kultura angielska, thum. M. Ugniewski, Warszawa 2000, s. 174, 284, 297.

4 E. Rostworowski, Historia powszechna. Wiek XVIII, Warszawa 1994, s. 233.

A. Kijas, Moskwa w relacjach polskich XVI i pierwszej połowy XVII wieku, [w:] Oblicza Wschodu w kulturze polskiej, pod red. G. Kotlarskiego i M. Figury, Poznań 1999, s. 53; Early Exploration of Russia, oprac. M. Poe, t. 1, London 2003, Introduction, s. 1.

6 J. S. Bystroń, Dzieje obyczajów w dawnej Polsce. Wiek XVI-XVIII, t. 1, Warszawa 1994, s. 130. Z wydań w r. 1960 i 1976 peerelowska cenzura wycięła bardziej krytyczne opinie o Rosjanach, Kozakach - mieszkańcach Rusi, zob. J. Tazbir, Rosjanie w literaturze polskiej XIX i XX w., [w:] Między Wschodem a Zachodem. Rzeczpospolita XVI-XVIII w. Studia ofiarowane Zbigniewowi Wójcikowi w siedemdziesiata rocznicę urodzin, Warszawa 1993, s. 252.

7 Zob. P. Lewin, Rusko-polskie zwiazki literackie, [w:] Słownik literatury staropolskiej. Średniowiecze - renesans - barok, pod red. T. Michałowskiej przy udziale B. Otwinowskiej i E. Sarnowskiej-Temeriusz, Wrocław 2002, s. 832.
} 
cieja z Miechowa „o dwóch Sarmacjach”, wydana w Krakowie w 1517 r., a potem thumaczona na wiele języków i wielokrotnie przedrukowywana w rozmaitych europejskich oficynach. Dziełko Miechowity odkrywające dla nauki Europę Wschodnia, a także historyczne i kartograficzne prace Bernarda Wapowskiego swą szczególną wartość zawdzięczały relacjom jeńców, zbiegów moskiewskich oraz polskich i litewskich uczestników wojen z Moskwą w początkach XVI wieku ${ }^{8}$. Kompilację dotychczasowej wiedzy z perspektywy schyłku XVI stulecia (ze szczególnym uwzględnieniem kroniki Długosza, publikacji Miechowity i Marcina Kromera ${ }^{9}$ ) stanowiła Kronika polska, litewska, żmudzka i wszystkiej Rusi Macieja Stryjkowskiego, wydrukowana w Królewcu w 1582 r. Stryjkowski, reprezentując tradycje polskiego dziejopisarstwa, równocześnie „najgłębiej pośród wszystkich autorów piszących aż po początek XIX w. wykorzystywał źródła litewsko-ruskie i ruskie" ${ }^{10}$. Nieco wcześniej w Krakowie Aleksander Gwagnin opublikował Sarmatiae Europae descriptio (1578) - zarys geograficzno-historyczny obejmujący także Tatarię i Moskwę, o którego autorstwo toczył spór ze Stryjkowskim. Dziełko to w barokowej Europie stało się często wykorzystywanym źródłem, wielokrotnie je wznawiano w drukarniach zachodnioeuropejskich, tłumaczono na włoski, niemiecki i czeski, wreszcie w rozszerzonej wersji opublikowano po polsku w $1611 \mathrm{r}$. Słabsze niż w Kronice są tu zabiegi integrujące polsko-litewsko-ruską przestrzeń kulturowa, choć dzięki swej popularności „najistotniejsze wypowiedzi Stryjkowskiego na temat polsko-litewskiej historii zostały spopularyzowane za pośrednictwem dzieła Guagniniego [Gwagnina]"11.

\footnotetext{
${ }^{8}$ Ów niezbyt obszerny, głównie geograficzny opis Europy Wschodniej (będący „W założeniu [...] pismem wybitnie polemicznym”, jak określa to Karol Buczek, zob. Maciej Miechowita jako geograf Europy Wschodniej [w:] Maciej z Miechowa 14571523. Historyk, geograf, lekarz, organizator nauki, red. H. Barycz, Wrocław - Warszawa 1960, s. 153) to najważniejsze dzieło Miechowity: Tractatus de duabus Sarmatiis Asiana et Europiana et de contentins in eis (1517), wydanie drugie pt. Descriptio Sarmatiarum Asianae et Europianae... (1521), przekład polski pt. Polskie wypisanie dwojej krainy świata (1535). Nazwy „Sarmacja Azjatycka” i „Europejska” występują już w literaturze antycznej. Miechowita nazywa Sarmacją Europejską obszar pomiędzy Wisłą a Donem, Azjatycka zaś miała rozciagać się do Morza Kaspijskiego. Autor w pewnym stopniu uwzględnił także zagadnienia historii ludów zasiedlających te obszary, sporo miejsca poświęcił właśnie państwu moskiewskiemu (zob. Księga druga, traktat drugi).

9 Zob. J. Radziszewska, Maciej Stryjkowski i jego dzieło, [w:] M. Stryjkowski, O poczatkach, wywodach, dzielnościach, sprawach rycerskich i domowych stawnego narodu litewskiego, żemojdzkiego i ruskiego..., oprac. J. Radziszewska, Warszawa 1978, s. 14.

10 D. Dąbrowski, Romanowicze w ,Kronice polskiej, litewskiej, żmudzkiej $i$ wszystkiej Rusi" Macieja Stryjkowskiego (ze szczególnym uwzględnieniem kwestii genealogicznych), „Senoji Lietuvos literatūra”, 22:2006, s. 147.

11 Zob. H.-J. Bömelburg, Polska myśl historyczna a humanistyczna historia narodowa (1500-1700), Kraków 2011, s. 589-592.
} 
Pełniejszy obraz Rosji ukształtował się w świadomości polskiej dopiero w wyniku kolejnych konfliktów - dymitriad i wojen srebrnego wieku, choć obok respektu dla siły militarnej państwa moskiewskiego niejednokrotnie zawierał też bardzo krytyczny osąd moskiewskiej grubianitatis, brutalności, skłonności do pijaństwa, ciemnoty i bezwolnego podporządkowania carom ${ }^{12}$. Bliższe kontakty przyniosły jednak pewną polaryzację stanowisk w postrzeganiu Moskwy, pojawiły się w literaturze tego okresu nawet teksty, „,w których wyraźnie pobrzmiewa inny, pozytywny stosunek" "13. Należy jednak zaznaczyć, że główne kontury negatywnego wizerunku państwa moskiewskiego i jego mieszkańców wywodzą się jeszcze z drugiej połowy XVI w. powielane, ,utrwalane i transponowane przez następne pokolenia literackie”, osiagają ,swój najwyższy wyraz artystyczny" w czasach romantyzmu ${ }^{14}$. Warto pamiętać, że ów samodzielny stereotyp „Moskwicina” mógł pojawić się dopiero u progu epoki nowożytnej, wcześniej bowiem - jak zauważa Janusz Maciejewski - nie wyodrębniano mieszkańców tego kraju ze wspólnoty staroruskiej ${ }^{15}$. Zdaniem Tadeusza Sucharskiego proces kształtowania jednoznacznie negatywnego obrazu Rosji rozciagnął się jednak na „długie lata wieku XVII”. Janusz Tazbir w kulturze baroku w Rzeczypospolitej dostrzega ogólniejszą tendencję do negatywnego traktowania wszystkich obcych, do oparcia relacji z zagranica ,na pewnych z góry przyjętych założeniach, a nie na rzeczywistej obserwacji”"

Oczywistą przeszkodę w gruntowniejszym poznaniu ludzi, kraju i jego dziejów dobitnie wyraził szwedzki dyplomata Peer Persson de Erlesunda (Petrus Petreius 1570-1622) ${ }^{17}$, który trzykrotnie odwiedził państwo moskiewskie i spędził tam łącznie kilka lat (1601-1605, 1608, 1611), pu-

12 A. Kijas, dz. cyt., s. 59-61; J. Tazbir, dz. cyt., s. 252. Owa „moskiewska grubianitas” stanowiła nadrzędną kategorię, determinując pozostałe wady, od niej pochodne. Zob. A. Kępiński, Lach i Moskal. Z dziejów stereotypu, Warszawa - Kraków 1990, s. 34.

${ }_{13}$ T. Sucharski, ,, Rosja wchodzi w polskie wiersze”- obraz Rosjanina w literaturze polskiej, [w:] Katalog wzajemnych uprzedzeń Polaków i Rosjan, red. A. De Lazari, Warszawa 2006, s. 88-90.

${ }_{14}$ A. Kępiński, dz. cyt., s. 41. T. Sucharski wymienia następujące cechy przypisywane Moskwie i jej mieszkańcom: to kraj i naród fałszywy, agresywny, zaborczy, tchórzliwy, dziki, barbarzyński, despotyczny, cierpliwie znoszący niewolę, niewierny, okrutny, dziedziczny wróg Rzeczypospolitej, o obcej kulturze, braku obyczajów, pozbawiony ogłady, znajdujący się w stanie cywilizacyjnej zapaści, oddający bałwochwalczą cześć carom. Zob. dz. cyt., s. 82-95.

15 J. Maciejewski, Stereotyp Rosji i Rosjanina w polskiej literaturze i świadomości społecznej, „Więź” 1998, nr 2, s. 184.

16 J. Tazbir, Stosunek do obcych $w$ dobie baroku, [w:] Swojskość i cudzoziemczyzna $w$ dziejach kultury polskiej, red. Z. Stefanowska, Warszawa 1973, s. 91.

17 Zob. Biographiskt Lexicon öfver namnkunnige svenska män, t. 5, Vahlström i Låstbom 1843, s. 164-168. 
blikując swe dzieło po szwedzku i po niemiecku: „Das aber der Reussen Land und dero Provincien mit ihren Sitten, Gebräuchen und Geschichten unbekandt und gleichsam im Finstern verborgen gelegen, ist die Ursach, weil in ihrem Land ein Gesetz und Gebrauch, dass keinem Frembden (ausgenommen den Legaten) in ihr Land zu reisen oder durch zuwandern verstattet und erlaubet wird, wie in andern Ländern gebräuchlich"18. $\mathrm{Z}$ tego powodu specjalnego znaczenia nabierały relacje dyplomatów, rozbudowywane niekiedy, dzięki dorobkowi poprzedników, w obszerniejsze opracowania z uwzględnieniem także kwestii historycznych. Dotyczy to zwłaszcza cenionego traktatu chorograficznego posła cesarskiego Sigismunda von Herbersteina (1486-1566) Rerum Moscoviticarum commentarii (Wiedeń 1549) ${ }^{19}$, który wykorzystał przy jego opracowaniu swe kilkukrotne pobyty w Polsce, uwzględniał też polską literaturę, głównie Macieja z Miechowa ${ }^{20}$. W podsumowującej okres do końca XVI w. edycji zbiorowej Rerum Moscoviticarum auctores varii unum in corpus nunc primum congesti (Frankfurt 1600), wydanej staraniem Marquarda Frehera (1565-1614), obok relacji Herbersteina znalazły swoje miejsce teksty Aleksandra Gwagnina, Macieja z Miechowa i Reinholda Heidensteina (na ogólną liczbę zgromadzonych tu 10) ${ }^{21}$.

18 Peer Persson de Erlesunda, Historien und Bericht von dem Grossfürstentumb Muschkow, Lipsk 1620, Vorrede (wersja szwedzka: Regni Muschowitici sciographia. Thet är: Eenwiss och egentelich Beskriffing om Rysland, Sztokholm 1614-1615). Problem swobody wjazdu i poruszania się po terytorium moskiewskim jest wzmiankowany przez kilku autorów XV - pocz. XVII w. już od Ambrogio Contariniego - A. Kijas, dz. cyt., s. 58, 60-61. W jednej z laudacji zamieszczonych na początku dzieła Perssona luterański teolog i filozof, znany polemista antysocyniański Jakob Martini (1570-1649) pisat: „Moscoviae, in terribus longum et sine nomine, terrae/Torpentis, laudum buccina nulla fuit,/Donec Petrejus, Suecorum oriundus ab oris/Illius insignes extenebraret agros". Nie oznacza to wcale, iż pomija się tu nazwiska poprzedników: Herbersteina, Macieja z Miechowa, Paula Giovio (1483-1552). Wspomina o nich ,et paucis quibusdam aliis” w dołączonym do dzieła Praefatio „T. Jo. Friderichus linguarum et historiarum professor”.

19 Z nowych opracowań zob. M. T. Poe, „A People Born to Slavery”. Russia in Early Modern European Ethnography 1476-1748, New York 2000, s. 117-144 oraz zbiór artykułów przygotowanych z okazji 450-lecia publikacji Herbersteina: 450 Jahre Sigismund von Herbersteins „Rerum Moscoviticarum commentarii” 1549-1999. Jubiläumsvorträge, red. F. Kämpfer i R. Frötschner, Wiesbaden 2002.

20 Zob. Early Exploration..., s. 19. Commentarii ,zdystansowały” i w dużej mierze zdezaktualizowały traktat Miechowity. „Z lektury tego dzieła wynosi się wrażenie, że Herberstein czuł głęboki uraz do Miechowity" i także dlatego zależało mu na doprowadzeniu do perfekcji swego dzieła, zob. K. Buczek, dz. cyt., s. 108, 153.

${ }^{21}$ Inna wersja: Rerum moscovitarum auctores aliquot (Hanau 1600). Marquard Freher (1565-1614) był posłem elektora Palatynatu Reńskiego Fryderyka IV Sprawiedliwego na dwór Zygmunta III. O jego osiagnięciach w dziedzinie edytorstwa źródeł zob. J. Kurkowski, Europejskie edytorstwo źródel historycznych w XVII-XVIII w. Próba wstęnej charakterystyki zjawiska, „Analecta. Studia i Materiały z Dziejów Nauki”, 21:2012, nr 1/2, s. 61-62; F. X. von Wegele, Freher, Marquard, [w:] Allgemeine Deut- 
Relacje z podróży i opisy poselstw pozostały specyficznym typem publikacji o sprawach moskiewskich także w XVII stuleciu, co podkreśla graniczność, a nawet pewną zewnętrzność tych obszarów wobec przestrzeni europejskiej i europejskiej świadomości, i to mimo definiowania ich zasięgu poprzez pojęcie christianitas. Wychodzenie Moskwy z zamkniętego ówcześnie bizantyńskiego kręgu rozpoczęło się w II połowie XVII w., początkowo właśnie za pośrednictwem polskiej kultury ${ }^{22}$.

Ze względu na intensywne w tym stuleciu polityczne i handlowe kontakty polsko-moskiewskie nie brakowało polskich pamiętników, relacji i opisów $\mathrm{z}$ autopsji ${ }^{23}$, choć niewiele $\mathrm{z}$ nich wówczas ujrzało światło dzienne (jak np. Jerzego Niemirycza Discursus de bello Moscovitio anni 1632 - Paryż 1632, Pawła Potockiego Moschovia sive brevis narratio de moribus magnae Russorum monarchiae - Gdańsk 1670 czy cudzoziemców w jawnej lub tajnej służbie Rzeczypospolitej: Bernarda Leopolda Franza Tannera [dworzanina Michała Jerzego Czartoryskiego] Legatio Polono-Lithuanica in Moscoviam - Norymberga 1680 Jacoba Reutenfelsa - De rebus Muschoviticis ad serenissimum magnum Hetruriae ducem Cosmum tertium - Padwa $1680^{24}$ ), pozostając w obiegu rękopiśmiennym lub dyplomatycznych archiwach bez wpływu na naukę europejską ${ }^{25}$. Większe znaczenie dla poznania wschodnich krańców kontynentu w XVI-XVII w. miały łacińskie wydania prac historycznych Macieja Stryjkowskiego, Aleksandra Gwagnina, Reinholda Heidensteina, Pawła Piaseckiego, Wojciecha Wijuka Kojałowicza, Wespazjana Kochowskiego itp. W ukształtowaniu stereotypowego ogólnoeuropejskiego kanonu podstawowych informacji o Rosji w XVII w.

sche Biographie, t. 7, Lipsk 1878, s. 334-335; szerzej: D. Kornexl, Studien zu Marquard Freher (1565-1614). Leben, Werke und gelehrtengeschichtliche Bedeutung, Bamberg 1967. Na temat wiedzy Europy o Rosji w dobie renesansu zob. S. Mund, Orbis russiarum, Genèse et développement de la représentation du monde «russe» en Occident à la Renaissance, Genève 2003.

22 J. Róziewicz, dz. cyt., s. 22-27. Istotną w tym rolę odegrało włączenie na stałe do Rosji ziemi smoleńskiej, czernihowskiej, a zwłaszcza lewobrzeżnej Ukrainy.

23 Wiele $z$ nich wiązało się z epoką dymitriad. Szerzej na ten temat zob. J. Róziewicz, dz. cyt., s. 21. Przypomnijmy, że istniał zwyczaj, a potem obowiązek, składania pisemnych relacji z poselstw, które sporządzali zwykle sekretarze legacji lub inne osoby z orszaku. Rzadko je publikowano. Zob. Historia dyplomacji polskiej, t. 2, red. Z. Wójcik, Warszawa 1982, s. 299-300.

${ }^{24}$ F. von Adelung, Kritisch-literarische Übersicht der Reisenden in Rußland bis 1700, deren Berichte bekannt sind, t. 2, Petersburg i Lipsk 1846, s. 348-349, 363. Reutenfels jest postacią dość tajemniczą, pojawiają się supozycje, że działał także jako agent polski w Moskwie. Zob. W. Bracewell, The Limits of Europe in East European Travel Writing, [w:] Under Eastern Eyes. A Comparative Introduction to East European Travel Writing on Europe, red. W. Bracewell, A. Drace-Francis, Budapest - New York 2008, s. 84.

${ }_{25}$ Jak choćby relacja z poselstwa Michała Haraburdy w $1573 \mathrm{r}$. 
swą rolę odegrała obszerna, ozdobiona licznymi rycinami relacja matematyka, geografa i bibliotekarza Adama Oleariusa (Ölschlägera 15991671) z przebiegu misji dyplomatycznej szlezwicko-holsztyńskiej do Moskwy. Przetłumaczona na kilka języków europejskich, była wielokrotnie wznawiana (z uzupełnieniami), a w wersji francuskojęzycznej (w thumaczeniu Abrahama de Wicqueforta, w kolejnych wzbogacanych edycjach) po raz ostatni wydana w Hadze jeszcze w roku $1727^{26}$. Historia została tam jednak potraktowana dość skrótowo (począwszy od panowania pierwszego cara rosyjskiego Iwana IV) i stanowi wstęp do prezentacji ustroju, elity władzy, sądownictwa, religii prawosławnej (tu także napotykamy historyczne wprowadzenie na temat poczatków chrześcijaństwa w państwie moskiewskim) ${ }^{27}$.

Odgórna próba okcydentalizacji Rosji, odnoszącej sukcesy polityczne i militarne, a zwłaszcza nawiązanie bezpośrednich kontaktów naukowych z Europa Zachodnia, zapoczattkowane tak spektakularnie w dobie reform Piotra Wielkiego, musiało wpłynąć na wzrost zainteresowania odległym (niemal egzotycznym) budzącym się mocarstwem i pojawienie się kolejnych publikacji na temat jego historii i aktualnego stanu. Warto przypomnieć, że kulturę XVIII stulecia charakteryzuje m.in. dążność do poszerzenia horyzontu geograficznego przestrzeni poznawczej (badawczej), nie mówiąc już o elitarnej modzie na egzotykę, a zwłaszcza na różnorodne artefakty świata Orientu ${ }^{28}$. W świadomości elit europejskich Rosja, przywrócona w wieku świateł do europejskiej wspólnoty, znalazła miejsce wśród krajów Północy, w zgodzie z równoleżnikowym, podstawowym podziałem kontynentu powszechnie wówczas stosowanym

${ }^{26}$ F. von Adelung, dz. cyt., t. 2, s. 299-306. Rosją interesowano się (zwłaszcza Anglicy) także ze względu na to, iż przez nią wiodła droga do bajkowego Wschodu (zwłaszcza Persji), zob. The Travels of Olearius in Seventeenth-Century Russia, wyd. S. H. Baron, Stanford 1967, Introduction, s. 3-4. Olearius tam właśnie dotarł.

${ }_{27} \mathrm{~W}$ wydaniu paryskim z $1666 \mathrm{r}$. i tak znacznie rozbudowano to wprowadzenie historyczne w stosunku do pierwszej edycji francuskiej z 1656 r. Por. A. Olearius, Relation du voyage de Adam Olearius en Moscovie, Tartarie et Perse, t. 1, s. 185-220 (dalej o ustroju i religii do s. 270); wyd. Paris 1656, t. 1, s. 113-121. Wydanie Amsterdam 1727 pod tytułem Voyages très-curieux et très-renommez faits en Moscovie, Tartarie et Perse, t. 1, s. 262-306. Zob. też W. Leitsch, Westeuropäische Reiseberichte über den Moskauer Staat, [w:] Reiseberichte als Quellen europäischer Kulturgeschichte. Aufgaben und Möglichkeiten der historischen Reiseforschung, red. A. Mączak i H. J. Teutenberg, Wolfenbüttel 1982, s. 153-176.

28 E. Rostworowski zwraca uwagę na skokowy charakter procesu poznawania pozaeuropejskiego świata: osiagnięcia przełomu XVII i XVIII w. zachowały swe znaczenie aż do połowy stulecia, zasadnicza zmiana nastapiła w latach 1770-1790, gdy ,dokonane [...] wielkie eksploracje lądów, mórz, literatur, kultur i obszarów «dzikości» pozaeuropejskiego świata otwieraja już bardziej horyzonty nadchodzącego XIX niż kończącego się XVIII w.”. E. Roztworowski, dz. cyt., s. 193. 
w kwestiach polityczno-geograficznych ${ }^{29}$. W nawiązaniu do tego podziału warto choć przez chwilę przyjrzeć się wizerunkowi Rosji i jej dziejów z perspektywy „Południa” - opiniotwórczego, promieniującego na całą osiemnastowieczną Europę kręgu kultury francuskiej.

Jakkolwiek bezpośrednie kontakty polityczne francusko-moskiewskie nawiązano już w czasach Iwana IV (m.in. przy okazji elekcji po śmierci Zygmunta Augusta), to nowy ich rozdział otworzył się dopiero w epoce Romanowów ${ }^{30}$. W pierwszej połowie XVII w. próbowano zawrzeć traktat handlowy i powołać francuską kompanię handlową (reaktywowano ten pomysł w czasach Colberta), a Francję odwiedzali carscy wysłannicy, jednak pierwsze poselstwo z prawdziwego zdarzenia (i należycie udokumentowane historycznie) dotarło z Moskwy do Wersalu dopiero w 1668 roku $^{31}$. Choć w drugiej połowie tego stulecia (od traktatów westfalskich) znaczenie Rosji w polityce europejskiej wyraźnie wzrosło, nadal stosunki francusko-rosyjskie miały dość incydentalny charakter, a francuska dyplomacja nie wykazywała głębokiego zainteresowania państwem carów, prowadząc zwykle działania antyrosyjskie poprzez rezydentów w Warszawie i Sztokholmie pod kątem swoich aliansów z Rzeczpospolitą i Szwecją ${ }^{32}$. Sytuacja ta zaczęła ulegać zmianie podczas wielkiej wojny północnej, czego sygnałem jest choćby instrukcja z 1702 r. dla korespondenta francuskiego (sekretarza ambasady?) w Rzeczypospolitej Jeana Casimira Baluze'a wysłanego z misją specjalną do cara ${ }^{33}$.

29 E. Rostworowski, dz. cyt., s. 137. Znajduje to odzwierciedlenie także w tytułach dzieł, np. P. A. La Place, J. F. Croix, A. Hornot, Anecdotes du Nord, comprenant la Suède, le Danemarck, la Pologne et la Russie, depuis l'origine de ces monarchies jusqu'à présent, Paris 1770 . Do rangi symbolu urasta fakt, że w pierwszych wydaniach relacji z podróży po krajach północnych lekarza i podróżnika Pierre’a Martina de La Martinière’a (1634-1690) Voyage des pays septentrionaux nie ma uwag o Rosji (Paryż 1672, 1676, 1682), zaś już do wydania angielskiego z $1706 \mathrm{r}$. w Londynie dołączono ,a particular relations of the court of the czar, of the religion and customs of the Muscovites and a short history of Muscovy" - A New Voyage to the North, s. 97-182 (na ogólną liczbę 257 ss. - te dodatki stanowia więc aż 1/3 tomiku). Publikacja Martina to pierwszy francuski opis Arktyki. O licznych thumaczeniach tego dziełka zob. F. von Adelung, dz. cyt., t. 2, s. 320-322.

30 Szerzej o tym: F. Grönebaum, Frankreich in Ost- und Nordeuropa. Die franzözisch-russischen Beziehungen von 1648-1689, Wiesbaden 1968 (Quellen und Studien zur Geschichte des Östlichen Europa, 2), s. 1-2.

31 Choć nie przyniosło właściwie żadnych politycznych skutków, było pierwszym bezpośrednim zetknięciem Rosji z kulturą wieku Ludwika XIV. F. Grönebaum, dz. cyt., s. 2-5, 46-62; M.-A. Chabin, Les Français et la Russie dans la première moitié du XVIIIe siècle. La famille Delisle et les milieux savants, Thèse pour le diplôme d'archivistepaléographe, École des chartes 1983 [édition 2013], Introduction: La France et la Russie jusqu'au XVIIIe siècle, s. 22-24, <http://www.archive17.fr/index.php?option=com docman\&task=doc_download\&gid=126\&Itemid $>$ (1 XII 2015).

${ }^{32}$ F. Grönebaum, dz. cyt., s. 123.

33 M.-A. Chabin, dz. cyt., s. 26; Historia dyplomacji polskiej..., s. 429. 
Ówczesna wiedza Francuzów o Rosji niewiele wykraczała poza schematyczne informacje (i stereotypy) Herbersteina i Oleariusa ${ }^{34}$. W 1698 r. pod pseudonimem (?) Foy de la Neuville (Neufville) ukazała się Relation curieuse et nouvelle de Moscovie, dość szybko przypisana znanemu (zwłaszcza z powodu pierwszej biografii Kartezjusza i polemik przeciw jansenistom) uczonemu Adrienowi Bailletowi (1749-1706), urodzonemu właśnie w Neuville ${ }^{35}$. Autor dziełka miał jako dyplomata odbyć misję na dwór Piotra I (1689). Mielibyśmy tu więc de facto do czynienia z literacką kompilacją na atrakcyjny temat ubraną $\mathrm{w}$ formę autorelacji z rzekomej misji dyplomatycznej - bowiem bibliotekarz adwokata parlamentu paryskiego François-Chrétiena de Lamoignona w takiej wyprawie brać udziału nie mógł. W autorstwo Bailleta watpił już w pierwszej połowie XIX w. Friedrich von Adelung, niedawno także wyraziła swój zdecydowany sprzeciw Isabel de Madariaga ${ }^{36}$. Z drugiej strony relacja ta bywa podejrzanie ogólnikowa, nie pozostaje wolna od podstawowych błędów, postaci, których samo istnienie jest watpliwe, komicznych nawet pomyłek w nazewnictwie ${ }^{37}$. Już z pierwszych słów wynikałoby, iż z Warszawy najkrótsza droga do Moskwy prowadzi przez Kijów ${ }^{38}$ ! Dziś wydaje się potwierdzone, że taki agent dyplomatyczny rzeczywiście istniał, choć bardzo niewiele o nim wiadomo ${ }^{39}$.

${ }^{34}$ O negatywnym obrazie Rosji, stojącej na niższym poziomie cywilizacyjnym zob. M. Mervaud, J. C. Roberti, Une infinie brutalité. L'image de la Russie dans la France des XVIe et XVIIe siècles, Paris 1991.

35 Identyfikacja autora jako Adriena Bailleta: N. Lenglet du Fresnoy, Méthode pour étudier l'histoire, Paris 1713, t. 1, s. 236; t. 2, s. 309; G. H. Stuck, Verzeichnis von älteren und neueren Land- und Reisebeschreibungen, t. 2, Halle 1787, s. 80. Zob. też F. Grönebaum, dz. cyt., s. 119-122.

36 F. von Adelung, dz. cyt., t. 2, s. 379-381; I. de Madariaga, Who was Foy de la Neuville? „Cahiers du Monde russe et soviétique”, 28:1987, nr 1, s. 21.

37 Np. „Stolitz” - jak niepoprawnie, zdaniem autora, nazywa się Moskwę - miałaby być rzeką (sic!) płynącą przez miasto, zob. I. de Madariaga, dz. cyt., s. 27.

${ }_{38}$ Relation curieuse et nouvelle de Moscovie, Paryż 1698, s. 2. Wolter korzystał z tego dziełka do opisu regencji Zofii Aleksiejewnej. Pierre-Charles Levesque uważał tę relację za fałszerstwo, wytykając to potknięcie Wolterowi (zob. poniżej), co z kolei uznaje za błąd A. S. Ławrow, niedawny edytor tego tekstu w wersji rosyjskiej (Moskwa 1996).

39 I. de Madariaga znalazła kilka wzmianek źródłowych o działalności de la Neuville'a. Twierdzi przy tym, że nigdy nie był agentem francuskim, lecz zaufanym króla Jana III (więc dalsze szczegóły o nim powinny znaleźć się w archiwach polskich). Jej zdaniem źródłem informacji Francuza są przede wszystkim własne obserwacje (obciążone zachodnioeuropejskimi stereotypami), a także np. informacje A. A. Matwiejewa (zob. o nim wyżej). Waţpi jednocześnie w trafność opisu poglądów księcia Golicyna (np. na temat uwolnienia chłopów). Zob. I. de Madariaga, dz. cyt., s. 27-30. W dawniejszej historiografii rosyjskiej uznawano de la Neuville'a za istniejącego realnie agenta francuskiego (M. P. Pogodin, N. W. Charykow), tak też określany był w encyklopediach sowieckich (zob. Советская историческая энциклопедия, t. 10, Moskwa 1967, szp. 90). A. S. Ławrow (1996) uważa de la Neuville'a za dyplomatę (znającego ojca królowej Marysieńki) w służbie polskiej i francuskiej. 
Niezależnie od tych watpliwości dziełko prezentuje bardzo tradycyjne oceny, nie dostrzegajacc - wraz upływem wieków - zmian ${ }^{40}$, w małym stopniu poszerza wiedzę o ówczesnej Rosji, drażniąc przy tym samego Leibniza swą autorską , chełpliwością”.

W momencie druku Relation pojawiły się już pewne nowe możliwości gromadzenia przez uczonych wiarygodnych informacji o Rosji oraz publikacji bardziej gruntownych opracowań historycznych i geograficznych $^{41}$. Świadectwem tej przemiany jest działalność rodziny uczonych Delisle'ów, znana dzięki dość obficie zachowanej dokumentacji w archiwach i bibliotekach (głównie francuskich) i studiom Marie-Anne Chabin. Claude Delisle (1644-1720), historyk i geograf, nauczyciel wielu możnych ludzi (m.in. młodego Filipa II Orleańskiego), potem królewski cenzor, przez lata zbierał materiały do przygotowywanej wielkiej historii powszechnej ${ }^{42}$, uwzględniając szeroko też dane geograficzne (jako komplementarne dla wiedzy historycznej). Korzystał przy tym z możliwości konfrontacji owych danych z ludźmi znającymi z autopsji różne słabo dotąd zbadane rejony świata ${ }^{43}$. W przypadku Rosji głównym konsultantem Delisle'a został ,gentilhomme moscovite" i dyplomata Piotr Postnikow ${ }^{44}$, z którym uczony kontaktował się przynajmniej trzykrotnie (w 1699, 1703 i 1707 lub 1708 r.), formułując liczne i zróżnicowane zapytania, także na piśmie (zatyt. „Questions à faire à l'ambassadeur de Moscovie”). Dotyczyły one szczegółów geograficznych (podziału na prowincje, demografii, sieci miejskiej, zagadnień etnograficznych, środowiska naturalnego - flory i fauny itd.), ustroju, religii, języka (pisowni nazwisk i nazw własnych, ich prawidłowej wymowy, właściwej latynizacji imion, znaczenia niektórych słów, podstaw gramatyki itd.), ale również kwestii historycz-

\footnotetext{
40 Są to opinie w rodzaju: „Les Moscovites sont à proprement parler des barbares”.

${ }^{41}$ W XVIII w. pojawił się sceptycyzm wobec wartości poznawczej relacji z podróży. O sceptycznym stanowisku Woltera zob. T. Strack, Exotische Erfahrung und Intersubjektivität. Reiseberichte im 17. und 18. Jahrhundert, Paderborn 1994, s. 16.

42 Drukowane źródła wiedzy C. Delisle o Rosji analizuje M.-A. Chabin, dz. cyt., s. 33-37. Spośród relacji z podróży schyłku XVII w. zna on publikacje cesarskiego posła Augustina de Mayerberga, jezuity Philippe'a Avrila, Foy de la Neuville'a oraz Jeana Struysa.

${ }^{43}$ M.-A. Chabin, dz. cyt., s. 33.

44 M.-A. Chabin, La curiosité des savants français pour la Russie dans la première moitié du XVIIIe siècle, „Revue des études slaves”, 57:1985, z. 4, s. 566. Postnikow już w 1690 r. wyruszył na Zachód, w 1698 r. przyłączył się do poselstwa Piotra I. W 1695 r. na uniwersytecie w Padwie otrzymał tytuł doktora medycyny. Od 1703 r. przynajmniej do 1709 r. pełnił rolę ambasadora rosyjskiego w Paryżu. Innym ewentualnym konsultantem $\mathrm{w}$ sprawach rosyjskich mógł być muszkieter, potem oficer, przyznający sobie rolę przedstawiciela cara Eleazar Krok, który przybył do Francji ok. 1680 r., a zmarł w 1711 r. M.-A. Chabin, Les Français et la Russie..., s. 37-38, 45.
} 
nych (także źródeł do dziejów Rosji), a zwłaszcza genealogii władców, uznawanej wówczas za niezbędna, wręcz podstawową część historycznego opisu kraju ${ }^{45}$.

Delisle nie zdażył jednak urzeczywistnić swych ambitnych planów wydawniczych. W rękopisie pozostała krótka historia Rosji - wstępny etap kompilacji ${ }^{46}$. W 1731 r. w Paryżu pośmiertnie opublikowano w siedmiu tomikach Abrégé de l'histoire universelle w układzie chronologicznym, gdzie jedynie wyjątkowo odnajdujemy informacje dotyczące historii państwa moskiewskiego. Część ostatnia, obejmująca dzieje od 1653 do 1714 r., jest w zasadzie tylko przeglądem polityki międzynarodowej Francji ${ }^{47}$. Czytelnik mógłby sądzić, że autor zupełnie nie zna losów wschodnich krańców kontynentu. Jakimś śladem kwerendy były (zdaniem M.-A. Chabin) publiczne wykłady Claude'a Delisle’a o Rosji, choć nic właściwie o nich nie wiadomo ${ }^{48}$.

Syn Claude'a, Guillaume Delisle (1675-1726), sławny geograf i kartograf (od 1702 r. członek Académie royale des sciences, od 1718 r. zaś „premier géographe du roi”, autor map wielu części świata), w 1706 r. opublikował mapę Rosji, dedykowaną ambasadorowi Andriejowi Artamonowiczowi Matwiejewowi (1666-1728) ${ }^{49}$. Wysoko oceniona przez samego cara (choć ów m.in. skorygował położenie Petersburga), stała się powodem nawiązania bezpośrednich kontaktów między uczonym a władca, utrzymywanych aż do 1721 r., gdy specjalny wysłannik cara przywiózł do korekty mapę Morza Kaspijskiego narysowaną w 1. 1719-1721 pod kierunkiem nawigatora Carla Van Verdena ${ }^{50}$. Ta sama misja zachęciła brata geografa - astronoma Josepha Nicolasa Delisle'a (1688-1768) - do przeniesienia się do Petersburga. Joseph-Nicolas pozostał w Rosji przez 21 lat (1726-1747). Obok głównych zajęć związanych z astronomią i kartografią zajmował się kolekcjonowaniem roślin, minerałów, książek rosyjskich, a także sporządzaniem zestawień historycznych i wy-

45 M.-A. Chabin, Les Français et la Russie..., s. 40-45.

46 M.-A. Chabin, dz. cyt., s. 45-49 (rękopis Archives nationales, Dépôt du Service hydrographique de la Marine, 2 JJ 82 I 84), taże, La curiosité des savants français..., s. 567.

47 Np. t. 5, s. 374-376, 407-408 (o wojnie z Rzeczpospolitą 1577-1582).

48 M.-A. Chabin, Les Français et la Russie..., s. 48-49.

49 M.-A. Chabin, La curiosité des savants français..., s. 567-568. O źródłowej podstawie mapy zob. M.-A. Chabin, Les Français et la Russie..., s. 53-58. Jego głównym atutem była właśnie znakomita umiejętność sporządzania map - R. Forycki, Droga do Rosji. Spór o imperium carów (1761-1839), Warszawa 2013, s. 32.

50 Guillaume miał na ten temat wystapienie w Akademii (24 XII 1721 r.), opublikowane pt. Remarques sur la carte de la mer Caspienne envoyée à L'Académie par sa Majesté Czarienne, [w:] Histoire de L'Académie royale des sciences. Anneé MDCCXXI, Paris 1721, s. 245-254. 
pisów ze źródeł. Jednocześnie stał się ważnym rezydentem „,république des lettres", służąc informacjami i pomocą wielu europejskim uczonym ${ }^{51}$. Posyłał też doniesienia o wydarzeniach w Rosji do gazet francuskich ${ }^{52}$. Można powiedzieć, że dzięki J.-N. Delisle'owi obraz Rosji we Francji stał się dużo wyraźniejszy. Wymiernym osiagnięciem była publikacja atlasu kartograficznego, składającego się z 19 map szczegółowych, pt. Atlas Rossicus (Petersburg 1745), opartego m.in. na wynikach specjalnie organizowanych wypraw badawczych, w których uczestniczył nie tylko młodszy brat uczonego Louis (Półwysep Kolski, Syberia - Wielka Wyprawa Północna), lecz także on sam (luty-grudzień 1740 r., Syberia wyprawa nad Irtysz i Ob) ${ }^{53}$. Joseph-Nicolas po powrocie do Francji $\mathrm{z}$ wielkim zbiorem różnorodnych materiałów projektował wydanie swego rodzaju encyklopedii o Rosji pt. Nouveaux mémoires sur la Russie, Sibérie et sur une partie des grands états voisins, ale śmierć przerwała to przedsięwzięcie podczas redagowania wstępu do dzieła ${ }^{54}$.

Tymczasem we Francji wizerunek Rosji i odgórnej okcydentalizacji nabrał cech charakterystycznych dla całego XVIII stulecia. Punktem zwrotnym była publikacja dzieła Woltera poświęconego Karolowi XII i wojnie północnej (1731), uzupełnionego później przez Histoire de l'empire de Russie sous Pierre le Grand (t. 1-2, 1759-1763). Wolterowski entuzjazm dla reform Piotra i przyspieszonej modernizacji kraju otwiera cały ciag wypowiedzi francuskich opartych na paradygmacie „le mirage russe” (jak nazywał to Albert Lortholary ${ }^{55}$ ) - Bernarda Fontenelle'a, Denisa Diderota, Friedricha Melchiora von Grimma i innych encyklopedystów aż po uwagi Jeana Claude'a Hippolyte'a Méhée de La Touche'a ${ }^{56}$. W tym nurcie główną rolę odgrywało przekonanie o ra-

51 M.-A. Chabin, La curiosité des savants français..., s. 572.

${ }_{52}$ Zob. np. Extrait d'une lettre de M. Delisle écrite de Petersbourg le 3 janvier 1730, „Mercure de France”, luty 1730, s. 378-383.

53 Louis (ur. w 1690 r.) był jedną z licznych ofiar Wielkiej Wyprawy Północnej (zmarł 22 X 1741). Wśród powodów opuszczenia Rosji przez J.-N. Delisle'a wymienia się oskarżenia o przesyłanie do Francji poufnych informacji kartograficznych. Nie doczekał w Rosji publikacji atlasu - R. Forycki, dz. cyt., s. 35-36.

54 M.-A. Chabin, La curiosité des savants français..., s. 571. Sama liczba map opracowanych podczas pobytu w Rosji wynosiła podobno około 200. Jego wypisy do dziejów Rosji miały chyba stanowić ową ,sławną kronikę rosyjską przywiezioną do Francji przez M. Delislee'a", a przechowywaną w Biurze Marynarki, o czym wspominał A.-G. Contant D'Orville we wstępie do Les fastes de la Pologne et de la Russie. Seconde partie contenant l'histoire de Russie, Paris 1769, s. VIII-IX.

55 Syntetyczne omówienie dawniejszej literatury na ten temat - I. Hanslik, Das Bild Ruslands und Polens im Frankreich des 18. Jahrhunderts, Frankfurt am Main - Bern New York 1985, s. 12-17.

56 W przypadku Méhée de La Touche'a w afirmacji rosyjskich stosunków i polityki odgrywały rolę pieniądze. Jak stwierdza Emil Kipa, był on „notorycznym szpiegiem 
cjonalności owych przemian, wynikającej z pryncypiów oświeceniowej nauki o rządzeniu i wzorców „oświeconej monarchii”. Wolterowskie ujęcie bezwzględnie dominowało aż do lat sześćdziesiątych, wpływając także na nurt kronikarski historiografii francuskiej reprezentowany przez Jacques'a Lacombe'a czy André-Guillaume'a Contanta D'Orville'a ${ }^{57}$. Zarówno w dawniejszych, jak i w najnowszych badaniach zgodnie zwraca się uwagę na publicystyczny, wewnętrzny kontekst dyskusji wokół Rosji w piśmiennictwie francuskim XVIII stulecia. Dla encyklopedystów „nowa Rosja” stanowiła nieco wyimaginowany, wyrazisty przykład możliwości szybkiego, zracjonalizowanego ulepszania świata i ważnej w tym roli oświeconych władców, co chętnie przyjmowała dbająca o oceny zewnętrzne Katarzyna II. Wynikały stąd zresztą pewne bariery w akceptacji rzeczywistego stanu rzeczy, wywołujące nawet otwartą polemikę rosyjsko-francuską (np. w 1773 r. na łamach „Journal encyclopédique" w sprawie encyklopedycznego artykułu $K n u t^{58}$ ). Dawne dzieje Rosji, słabo znane i lekceważone, przedstawiano jako niezbyt istotne tło lub raczej kontrast dla jej spektakularnego osiemnastowiecznego rozwoju. Taki właśnie wizerunek jest charakterystyczny dla ówczesnych francuskich encyklopedii, w których dominowała wolterowska wizja z podkreślaniem roli dwojga wybitnych władców: Piotra I oraz Katarzyny II ${ }^{59}$. Drugie, przeciwstawne spojrzenie na Rosję reprezentowała grupa autorów znających ów kraj z autopsji lub jakoś związanych z Rzeczpospolitą (Jean-Baptiste Chappe D'Auteroche, Claude-Carloman de Rulhière, Nicolas Baudeau, Jean Jacques Rousseau, Jean-Philippe Garran de Coulon, Jean-Henri Castéra i Charles François Philibert Masson). Sprowokowani przez jednostronne, czasem odległe od rzeczywistości opinie Woltera, wytykali błędy w wyidealizowanym obrazie współczesnej Rosji, podkreślali pominięte zagadnienia (jak np. położenie chłopów), widząc zasadniczą sprzeczność pomiędzy tamtejszą praktyką despotyczną i projektem, aby wolni ludzie żyli w „europejskich” warunkach i strukturach społecznych, przy

rosyjskim, pobierającym stałą pensję z ambasady”. Wraz z Karolem Glave-Kolbielskim wydawal „Gazette de Varsovie” w latach 1791-1793, zob. PSB, t. VIII, s. 39. Szczyt „mirażu rosyjskiego" przypada na okres od 1770 r., po publikacji odpowiedzi Katarzyny II na Voyage en Sibérie Chappe D’Auteroch'a, zob. R. Forycki, ,Światła w ciemności”. O osiemnastowiecznej fascynacji Rosja we Francji, „Przegląd Wschodni”, 12:2013, z. 4, s. $785-789$.

57 I. Hanslik, dz. cyt., s. 296.

58 M. Mervaud, Le knout et l'honneur des Russes (à propos de deux articles de l'Encyclopédie), „Recherches sur Diderot et sur l'Encyclopédie”, 14:1993, s. 111-124.

59 Na ten temat zob. M. Belissa, La Russie mise en Lumières. Représentation et débats autour de la Russie dans la France du XVIIIe siècle, Paris 2010. 
objaśnianiu zaś braku realnego postępu w tym zakresie powracali do takich kategorii jak „,cechy narodowe" ${ }^{60}$. Inge Hanslik słusznie podkreśla współzależność opinii o Polsce i Rosji, pewną komplementarność ich historiograficznego obrazu. Warto przy tej okazji zaznaczyć, że właśnie wtedy ukształtowała się koncepcja „Europy Wschodniej” jako swoistej agregacji rozmaitych krajów i ludów, zmieniająca w kulturowej, intelektualnej pespektywie utrwalony równoleżnikowy podział kontynentu o tradycjach jeszcze renesansowych (zob. wyżej). Klucz etnograficzny do owej „Europy Wschodniej” stanowili Słowianie, stąd np. w Wielkiej encyklopedii język węgierski zaliczono do grupy słowiańskiej ${ }^{61}$.

Dydaktyzm tej polemiki dotykającej spraw Rosji i Polski sprzyjał powierzchownym, publicystycznym, wartościującym sądom, niepodbudowanym gruntowniejszą wiedzą historyczną. Już Stanisław Kot zwracał uwagę, że literatura francuska, „która w wieku XVIII zapanowała nad opinią publiczną kontynentu", zerwała z erudycyjną dążnością do systematyzacji oraz gruntownego wykładu i nabrała charakteru ,wybitnie reformistycznego" - publicystycznego. Rzeczpospolita, jako utarty wówczas przykład feudalnego systemu i anarchii politycznej, nie mogła więc dostarczać pozytywnych wzorców ${ }^{62}$. Powierzchowność i utylitarność opinii dotyczyła także dawnych i nowszych dziejów Rosji. Zmianę tego stanu rzeczy zwiastowały dopiero studia Pierre'a-Charles'a Levesque'a (1736-1812), który nie tylko miał za sobą siedmioletni pobyt w Rosji (jako protegowany przez Diderota nauczyciel w Szkole Kadetów i Akademii Sztuk Pięknych w Petersburgu), kwerendy w tamtejszych bibliotekach i archiwach, ale znał rosyjski, a nawet staro-cerkiewno-słowiański. Swych wniosków i opinii nie formułował więc na podstawie krótkich odwiedzin kraju i lektury paru pamiętników ${ }^{63}$. Levesque uważał zreszta, że dla mieszkańca Francji napisanie prawdziwej historii Rosji jest zadaniem prawie niemożliwym - kiedy dysponuje się jedynie mało wiarygodnymi, pełnymi przeinaczeń relacjami pośrednimi.

${ }^{60}$ I. Hanslik, dz. cyt., s. 295-297. O przełamywaniu „oświeceniowego fantazmatu” na temat Rosji zob. R. Forycki, Droga do Rosji..., s. 30, 51-62.

${ }^{61}$ L. Wolff, Inventing Eastern Europe, The Map of Civilisation on the Mind of the Enlightenment, Stanford 1994, s. 4, 356-357: „Eastern Europe is a cultural construction, an intellectual invention, of the Enlightenment". Zob. hasło Hongrie autorstwa Louisa de Jaucourt (1704-1779) Encyclopédie, ou Dictionnaire raisonné des sciences, des arts et des métiers, t. 8, Paryż 1766, s. 284-286: „La langue hongroise est un dialecte de l'esclavonne, et par conséquent elle a quelque rapport avec les langues de Bohème, de Pologne et de Russie". s. 177.

62 S. Kot, Rzeczpospolita Polska w literaturze politycznej Zachodu, Kraków 1919,

${ }^{63}$ I. Hanslik, dz. cyt., s. 190. 
Jego ceniona pięciotomowa synteza Histoire de Russie (Paryż 1782, fakt. 1781, kolejne wydania tamże 1783, poszerzone 1800 i pośmiertne 1812 - niedługo przed atakiem Wielkiej Armii) istotnie wpłynęła nie tylko na obraz dziejów Rosji na zachodzie kontynentu ${ }^{64}$, ale także na historiografię rosyjska ${ }^{65}$. Levesque przede wszystkim staranniej podszedł do dziejów średniowiecznej Rusi i uwzględnił najobszerniejszy wśród autorów epoki zestaw kronik, kompendiów i zbiorów praw (ze szczególną rolą drukowanych, bowiem kilka ważnych źródeł i opracowań wydano w Rosji w latach sześćdziesiątych tegoż stulecia). Dodać należy, iż w 1804 r. Levesque opublikował po francusku zbiór dawnego ruskiego prawodawstwa (Русская правда) ${ }^{66}$ według edycji Iwana $\mathrm{N}$. Bołtina. Główna myśl przewodnia syntezy francuskiego badacza prowadzi do osłabienia kontrastu pomiędzy epokami w dziejach Rosji. To przesada w podkreślaniu dawnego ruskiego „barbarzyństwa” jest - zdaniem Levesque'a - powodem przeceniania roli procesu modernizacji i zasług modernizatorów państwa rosyjskiego. Jego ocena Piotra I odbiega od apoteozy Woltera, a dzieło „króla filozofów” w wielu szczegółach podlega krytyce i sprostowaniom. W podsumowaniu panowania Piotra I stwierdza, że być może bez niego Rosjanie byliby tacy sami albo nawet lepsi, chyba że stanęłyby na przeszkodzie jakieś nieprzewidziane trudności ${ }^{67}$. Główną zaletą dzieła są jednak nie oceny i przypuszczenia, lecz solidna faktografia, choć autor brał tu pod uwagę opinię rosyjskiego dworu, o czym świadczą zmiany i uzupełnienia dokonane w wydaniach z czasów napoleońskich ${ }^{68}$.

${ }^{64}$ Dość powszechnie Levesque uznawany był za autorytet w zakresie dziejów Rosji, choć nie brakowało ostrych polemistów, jak Nicolas-Gabriel Leclerc (właść. Clerc 17261798), autor sześciotomowej (in $4^{\circ}$ ) Histoire de la Russie ancienne et moderne, Paryż 1783-1794. Z tym dziełem polemizował z kolei I. Bołtin (Болтин, И., Примечания на историю древния и нынешния России г. Леклерка, t. 1-2, Petersburg 1788).

65 V.A. Somov, Pierre-Charles Levesque. Protégé de Diderot et historien de la Russie, „Cahiers du monde russe”, 43:2002, nr 2-3, s. 275 (przyp. 4). To także drugie (po Historii Imperium Rosyjskiego za panowania Piotra Wielkiego Woltera) francuskie dzieło o dziejach Rosji wsparte przez elity rosyjskie m.in. poprzez liczne uczestnictwo w prenumeracie (zob. tamże, s. 282). Sama Katarzyna II miała natomiast żywić „nienawiść" do tego dzieła, stąd wypływała podobno zachęta do poszukiwania w nim błędów. Zob. A. Mazon, Pierre-Charles Levesque, humaniste, historien et moraliste, „, Revue des études slaves", 42:1963, s. 60.

${ }_{66}$ A. Mazon, dz. cyt., s. 65.

67 „Enfin, il est probable que, si Pierre n'avait pas régné, les Russes seraient aujourd'hui ce qu'ils sont, et peut-être mieux qu'ils ne sont, à moins que des obstacles imprévus ne les eussent arrêtés". P.-Ch. Levesque, Histoire de Russie tirée des chroniques originales, de pieces authentiques, et des meilleurs historiens de la nation, t. 4, Paris 1782, s. 532.

68 V. A. Somov, dz. cyt., s. 285. 
Kazimierz Bartkiewicz w podrozdziale o podstawach rekonstrukcji miejsca Polski w dziejach europejskich zamieszczonym w książce pt. $O b$ raz dziejów ojczystych w świadomości historycznej w Polsce doby Oświecenia stwierdza, iż w latach czterdziestych i pięćdziesiątych XVIII w. „stan piśmiennictwa traktującego o dziejach Europy równał się niemal zeru. W epoce Oświecenia urósł on, sumarycznie rzecz biorąc, do około 60 tytułów dzieł"69. Zbiór tych publikacji dzieli na trzy mniej więcej równe grupy, z których pierwsza odnosiła się ogólnie do dziejów powszechnych, druga koncentrowała się na wybranych zagadnieniach, a zwłaszcza kwestiach traktatów międzynarodowych oraz historii Kościoła i reformacji, trzecia zaś omawiała dzieje poszczególnych państw. Bartkiewicz ogranicza swe zestawienie do publikacji historycznych sensu stricto. Warto zaznaczyć, że opracowanie traktujące historiografię w szerszym rozumieniu - w zgodzie z ówczesną ,praktyką szkolną i badawczą”, która nie wyznaczała ostrych granic pomiędzy historia, geografia, a nawet teologią i publicystyką - dowodzi, iż w myśli historycznej doby Augusta III wyraźnie widać wzrost zainteresowania światem zewnętrznym, a zwłaszcza historią i geografią państw zachodnioeuropejskich ${ }^{70}$.

Klasyfikacja Bartkiewicza nie w pełni uwzględnia szczególnie charakterystyczną dla tamtej epoki grupę publikacji historycznych, a mianowicie edycje i reedycje źródeł. Trafnie autor natomiast zalicza kodeksy dyplomatyczne do prac poświęconych ,dziejom i aktualnemu stanowi traktatów międzypaństwowych”. W ramach historiografii erudycyjnej, gdzie „źródła i fakty powinny same mówić za siebie", tego typu publikacje zastępowały tradycyjną narrację historyczną. Edycje źródeł prawa międzynarodowego obejmowały oczywiście także zagadnienia dziejów stosunków z Moskwą i Rosją. Przypomnijmy tu pokrótce barwne losy tomów kodeksu dyplomatycznego Macieja Dogiela poświęconych tej tematyce. Za życia autora druk tomu drugiego, dotyczącego Rosji, i tomu trzeciego, poświęconego Litwie, został udaremniony przez stanowczy protest przedstawiciela dworu petersburskiego $^{71}$. W $1765 \mathrm{r}$. podjęto prace nad kontynuacją dzieła uczonego pijara, ale już pod nadzorem królewskim. Zadanie publikacji kolejnych tomów Kodeksu pozostawiono formalnie pijarom wileńskim, jednak w Warszawie powstał kilkunastoosobowy zespół składający się z doświadczonych sekre-

${ }^{69}$ K. Bartkiewicz, Obraz dziejów ojczystych w świadomości historycznej w Polsce doby Oświecenia, Zielona Góra 1979, s. 209.

70 Zob. D. Dolański, Zachód w polskiej myśli historycznej czasów saskich, Zielona Góra 2002, s. 5, 260.

71 J. Kurkowski, Z dziejów polskiego edytorstwa źródeł historycznych. Maciej Dogiel (1715-1760) „Analecta. Studia i Materiały z Dziejów Nauki”, 15:2006, nr 1/2, s. 115. 
tarzy, metrykantów i kopistów, którzy pod kierunkiem pisarza wielkiego koronnego Jacka Ogrodzkiego selekcjonowali, kopiowali, kolacjonowali i redagowali materiały źródłowe. Materiały krążyły pomiędzy Warszawą a Wilnem, co rzecz jasna wydłużało cały cykl przygotowań edytorskich. Prace z pewnością nie były prowadzone wyłącznie w celu badawczo-edytorskim, stąd dodatkowy nadzór ministrów i samego króla Stanisława Augusta, skoncentrowany na politycznej wymowie publikowanego materiału źródłowego ${ }^{72}$. Główny wysiłek skierowany został właśnie na zagadnienia stosunków ze Wschodem. Aby edycja była użyteczna dla szerszego kręgu odbiorców, podjęto decyzję o tłumaczeniu tekstów ruskich na łacinę. W pracach tych istotną rolę odgrywał sekretarz królewski Antoni Korwin Kossakowski (1718-1786), znawca języka rosyjskiego, który przygotował w 1768 r. ,z słowiańskiego na polski przetłumaczone” Opisanie państwa moskiewskiego (zob. poniżej), późniejszy tłumacz komedii autorstwa Katarzyny $\mathrm{II}^{73}$, specjalista $\mathrm{w}$ zakresie paleografii ruskiej ${ }^{74}$. Z korespondencji wiadomo, iż był on zwolennikiem bardzo dokładnego kolacjonowania materiałów ${ }^{75}$. Na początku lat siedemdziesiątych tom ,,moskiewski” był gotowy i, jak świadczy dość zagadkowy list z 23 września 1773 r. zachowany w korespondencji króla, wówczas miał rozpocząć się jego druk w oficynie warszawskich jezuitów. Na przeszkodzie stanął tym razem zakaz marszałka sejmu rozbiorowego, księcia Antoniego Ponińskiego, jednak list zawiera adnotację: „Gdym marszałkowi Ponińskiemu wyeksplikował, że to nie diariusz, ale zbiór, już dawniej aktów drukowanych, [...] zakaz podniósł"76. Do publikacji jednak nie doszło, jej śladów brak także w inwentarzu zasobów warszawskiej drukarni jezuickiej ${ }^{77}$. Po upadku Rzeczypospolitej o ogłoszeniu niewydanej części dzieła Dogiela zamyślał Hugo Kołłątaj (projekt z 1802 r.) i Towarzystwo Przyjaciół Nauk ${ }^{78}$. W tym ostatnim przedsięwzięciu uczestniczyć miał znany rosyjski bibliofil i kolekcjoner, kanclerz Ni-

${ }^{72}$ Zob. tamże, s. 116-121.

73 Tłumaczenie nosi datę 7 marca 1786 r., BUW, rps 1069.

74 O Kossakowskim, który w swym awanturniczym życiu miał być m.in. guwernerem w Moskwie, zob. E. Aleksandrowska, Kossakowski Antoni h. Ślepowron, przydomek Korwin (1735-1798), PSB, t. XIV, s. 261-262.

75 Tymczasem pijarzy wileńscy „nie dowierzali wiadomości swej w ruszczyźnie” - zob. list Jana Kantego Wykowskiego do Jacka Ogrodzkiego z 8 czerwca 1767 r., Kraków, Bibl. Czartoryskich, rps 692.

${ }_{76}$ Kraków, Bibl. Czartoryskich, rps 799, s. 207. List adresowany jest: „pour Monsieur de Glaire [Maurice Glayre], conseilleur privé du Roi”.

77 Zob. W. Gramatowski, Franciszek Bohomolec - wydawca, prefekt drukarni i redaktor „Wiadomości Warszawskich”, „Roczniki Biblioteczne”, 14:1970, z. 3-4, s. 544-545. Por. J. Kurkowski, dz. cyt., s. 120.

78 I. T. Baranowski, Udziat Stanisława Augusta i jego otoczenia w przygotowaniu Kodeksu Dyplomatycznego Polski, „Przegląd Historyczny”, 12:1911, z. 2, s. 255-256. 
kołaj Piotrowicz Rumiancow (1754-1826). „Tu jednak znów wyszły na jaw usterki tekstualne i S. B. Linde wobec braku wskazówek co do pochodzenia traktatów (zwłaszcza z Moskwą i Turcją w t. II) nie podjął się ich kolacjonowania. Dziś ów olbrzymi tom II w 2 częściach, bezkrytycznie skopiowany z oryg. Dogiela ok. 1820, zrewindykowany z Rosji, należy do Bibl. Narodowej w Warszawie" - pisał Władysław Konopczyński przed wojną w biogramie Dogiela ${ }^{79}$. Rzeczywiście, Wykaz rękopisów odebranych z cesarskiej Bibl. Publicznej w Piotrogrodzie za czas od 14 XI 1922 do 19 II 1924 pod numerem 5707 (sygn. Różn. F IV 143) wymienia rękopis ze zbioru Towarzystwa Przyjaciół Nauk pt.: „Dogiel Codex diplomaticus Regni Pologni [sic!] 1) Rosja 2) Turcja, Tatarzy, Kozacy fol. 558+709 2 tomy"80. Tomy te uległy zniszczeniu w 1944 roku $^{81}$.

Kodeks Dogiela to jeden z najbardziej znanych składników programu edytorskiego realizowanego przez środowisko skupione wokół Biblioteki Załuskich. W ramach tego programu dokonano także innych edycji bądź reedycji, które należałoby włączyć do zbioru publikacji historycznych ukazujących dzieje wschodniego sąsiada Rzeczypospolitej. Już w 1747 r. po wielu staraniach referendarza koronnego Józefa Andrzeja Załuskiego ${ }^{82}$ ukazał się w Warszawie w drukarni jezuickiej zbiór łacińskich pism Pawła Potockiego pt. Opera omnia. Zamieszczono tam przedruk wspomnianego już wyżej wydania gdańskiego z 1670 r. dziełka Moschovia sive brevis narratio de moribus magnae Russorum monarchiae, które powstało podczas niemal trzynastoletniego pobytu późniejszego kasztelana kamienieckiego i ojca prymasa Teodora Potockiego w niewoli moskiewskiej (1655-1667). W tych kilkuletnich usilnych staraniach o reedycję badacze doszukują się planu neutralizacji niechęci Potockich do referendarza koronnego aspirującego o godność biskupią jak również zamiaru podkreślenia pokrewieństwa Załuskich z Potockimi, a przede wszystkim własnych zasług dla kultury polskiej - wobec „kłopotów z inauguracją" publicznej biblioteki Załuskich ${ }^{83}$.

79 PSB, t. V, s. 281-282. Wg informacji podanej w Nowym Korbucie, w Bibliotece Rumiancowa miały znajdować się tomy 2 i 3 dzieła Dogiela, zob. tamże, t. 4 (Oświecenie), Warszawa 1964, s. 437.

80 BN, rps akc. 4722.

81 Zob. Katalog rękopisów Biblioteki Narodowej, red. K. Muszyńska, J. Kupść, seria II, t. II, s. 566-567.

${ }^{82} \mathrm{Na}$ ten temat zob. P. Buchwald-Pelcowa, Drukowi winniśmy oświecenie naszego wieku... Rola ksiażki w drodze ku Oświeceniu, Warszawa 2003, s. 109-112; S. Roszak, Koniec świata sarmackich erudytów, Toruń 2012, s. 153-157.

${ }_{83}$ Zob. J. Kozłowski, Szkice o dziejach Biblioteki Załuskich, Wrocław 1986, s. $137-$ 157 - rozdział IV: Biblioteka Załuskich - klopoty z inauguracja. P. Buchwald-Pelcowa, Inicjatywy wydawnicze Zaluskich, [w:] Bracia Zaluscy. Ich epoka i dzieło, pod red. D. Dukwicz, Warszawa 2011, s. 200-201. 
Warto jednak też spojrzeć na merytoryczną wartość niewielkiej, co prawda, publikacji Potockiego. Mirosław Nagielski podkreśla, że to „doskonałe na owe czasy studium o religii, ustroju, prawach i wojsku Moskwy”, które zawiera także spisy (wraz z krótką charakterystyka) dostojników państwowych, wojewodów, bojarów oraz okolniczych ${ }^{84}$. Dziełko ujawnia przy tym gruntowne klasyczne wykształcenie autora, który przedstawił moskiewskie rozwiązania ustrojowe, odwołując się do opinii i informacji m.in. Tacyta, Liwiusza, Kurcjusza Rufusa, Juwenalisa, Cycerona, Seneki, Waleriusza Maksimusa, a także korzystając ze znanych łacińskich epitom, a zwłaszcza Epitome Historiarum philippicarum Pompei Trogi Marcusa Iunianusa Justinusa - źródła analogii dla opisu wielu kwestii, np. tyranii carów poprzez paralelę do rządów Filipa w państwie macedońskim ${ }^{85}$.

W łacińskiej wersji kolekcji historyków polskich przygotowywanej przez środowisko Biblioteki Załuskich odnajdujemy także reedycje kilku dzieł wymienionych już powyżej w przeglądzie bibliografii podmiotowej. Tom pierwszy Historiarum Poloniae et Magni Ducatus Lithuaniae... collectio magna (Warszawa 1761) zawiera Sarmatiae Europae descriptio A. Gwagnina oraz Tractatus de duabus Sarmatiis Macieja z Miechowa ${ }^{86}$. Tom ten jest wzorowany na układzie treści zbioru Johanna Pistoriusa (1546-1608) $)^{87}$ Polonicae historiae corpus, hoc est Polonicarum rerum latini recentiores et veteres scriptores, quotquot extant, uno volumine compraehensi omnes et in aliquot distributi tomos (Bazylea 1582). Stamtąd także zaczerpnięty został wyciag na temat Litwy, pochodzacy z dzieła Herbersteina Rerum Moscoviticarum commentarii ${ }^{88}$. Edytor i drukarz „pan Micler notami ozdobił” wydanie z 1761 r., nadając mu specyficzny

\footnotetext{
${ }^{84}$ M. Nagielski, Potocki Pawet h. Pilawa, PSB, t. XXVIII, s. 118.

85 I. Lewandowski, Recepcja rzymskich kompendiów historycznych $w$ dawnej Polsce: (do połowy XVIII wieku), Poznań 1976, s. 103. Ulubieni historycy Potockiego to Tacyt, Liwiusz i Kurcjusz Rufus. W swych utworach korzysta także z epitom Florusa i Justinusa. W okresie baroku następuje charakterystyczna zmiana funkcji epitom w literaturze historycznej - jak u Potockiego stają się one źródłem analogii lub w znacznie większej mierze niż w poprzedniej epoce ważnym wzorcem stylistycznym. Szczególnie epitoma Florusa odpowiadała treścią sarmackim wyobrażeniom o starorzymskich wzorach republikańskich (tamże, s. 151).

${ }^{86}$ Historiarum..., t. 1, s. 36-114, 177-216. Zgodnie z poglądem J. A. Załuskiego sporne dziełko występuje tu pod nazwiskiem M. Stryjowskiego. Zob. J. A. Załuski, Biblioteka historyków, prawników, polityków i innych autorów polskich lub o Polsce piszacych z przypisami Józefa Epifaniego Minasowicza, wyd. J. Muczkowski, Kraków 1832, s. 22.

${ }^{87}$ Na temat biografii Pistoriusa młodszego i jego ojca zob. H.-J. Günther, Die Reformation und ihre Kinder, dargestellt an ,Vater und Sohn Johannes Pistorius Niddanus”. Eine Doppelbiographie: J. Pistorius d. Ä. (1502-1583) und J. Pistorius d. J. (15461608), Nidda 1994.

${ }^{88}$ Historiarum..., t. 1, s. 217-227.
} 
dla oświeceniowego piśmiennictwa charakter ${ }^{89}$. Ów edytorski komentarz obejmował bowiem też uwagi dydaktyczno-publicystyczne odnoszące się do aktualnego stanu Rzeczypospolitej. Jedna z nich była powodem pozwu i procesu przed sądem marszałkowskim, a dotyczyła drażliwych kwestii stosunków ze wschodnim sąsiadem. Wawrzyniec Mitzler de Kolof w przypisie $132 \mathrm{w}$ następujący sposób odniósł się do objęcia tronu kurlandzkiego przez Karola Krystiana Wettyna, syna Augusta III: „[Karol] ut dicam ut res est, Augustissimae Elisabethae, omnium Russorum Imperatricis gratia magis hunc ducatum [tj. Kurlandię], quam Polonorum beneficio obtinuit". Nawet broniący Mitzlera kanclerz Jan Małachowski, który podkreślał w swym liście do J. A. Załuskiego, iż „ten człek nie zgrzeszył ultro et malitiose”, dodawał jednocześnie: ,ale w tym, że powinien był ad superiores in materia status się odezwać [...]"90. Publicystyczny temperament edytora spowodował, że prymas Władysław Łubieński w mowie na radzie senatu z 25 października 1762 r., polecając jego prace szczodrobliwości senatorów, czuł się w obowiązku dołączyć takie zastrzeżenie: „ale to źle, że [ukazują się] bez powinnej cenzury i approbacjej"91. Taki niecodzienny typ komentarza edytorskiego spotykamy już zresztą w Mitzlerowskim wydaniu dzieła siedemnastowiecznego historyka Wawrzyńca Rudawskiego (1617-1690?) pt. Historiarum Poloniae ab excessu Vladislai IV ad pacem Olivensem usque libri IX (Warszawa i Lipsk 1755). Sens tych krytycznych uwag o sytuacji ustrojowej, społecznej i politycznej Rzeczypospolitej koresponduje zresztą z poglądami prezentowanymi w czasopismach wydawanych przez Mitzlera ${ }^{92}$.

Druk polskojęzycznej wersji „kolekcji historyków polskich” przypadł na pierwsze lata panowania Stanisława Augusta. Wcześniej główni inicjatorzy - Józef Andrzej Załuski i Józef Aleksander Jabłonowski - przeprowadzili długą korespondencyjną dyskusję nad jej koncepcją kompozycją i zakresem merytorycznym, która z oczywistych względów musiała także dotyczyć zamiarów i oczekiwań związanych z tak obszerną i kosztowną publikacją. Przy tej okazji dały o sobie znać charakterystyczne nurty refleksji o roli edytorstwa źródeł historycznych w ówczesnej kulturze

89 Wawrzyniec Mitzler de Kolof (1711-1778) to wyznawca filozofii Christiana Wolffa i zwolennik społecznych i artystycznych koncepcji Johanna Christopha Gottscheda. Wpływ na jego poglądy miała także tradycja myśli platońskiej. Zob. na ten temat L. Felbick, Lorenz Christoph Mizler de Kolof. Schüler Bachs und pythagoreischer ,Apostel der Wolffischen Philosophie”, Hildesheim-Zürich-New York 2012 (recenzja J. Kurkowskiego [w: , Kwartalnik Historii Nauki i Techniki”, 60:[2015], nr 2, s. 249-254).

90 BN, rps III 3261. Szerzej o tym zob. J. Kurkowski, Warszawskie czasopisma uczone doby Augusta III, Warszawa 1994, s. s. 208, 247.

91 BUW, rps 115, k. 123.

92 Zob. J. Kurkowski, dz. cyt., s. 197-241. 
umysłowej Rzeczypospolitej. Jabłonowski stwierdzał tam m.in.: „Władysławowskie zwycięstwa, Kazimierzowskie zwycięstwa, nieszczęścia i intrygi, Janowskie zwycięstwa i intrygi naród lub niech trwożą, lub ocuca - dlatego potrzebne panowania onych pamiątki i wielką dla ojczyzny przysługa" 93 .

Nie może być kwestią przypadku, że w tomie drugim Zbioru dziejopisów polskich zamieszczono przedruk całości kroniki Stryjkowskiego (z jedynego wydania w Królewcu w roku 1582), ukierunkowując komentarz edytorski i aneksy na kwestie dawnych i ,nowych” dziejów państwa rosyjskiego. Dodajmy tu, że wydanie królewieckie musiało rzeczywiście być w połowie XVIII w. rzadkością, skoro nawet Biblioteka Załuskich posiadała tylko dwa niekompletne egzemplarze i obu trzeba było ,zażywać, szukając w drugim egzemplarzu tych kart, których w jednym niedostawało"94. Prefekt drukarni jezuickiej w Warszawie Franciszek Bohomolec (1720-1784) w swej przedmowie wymieniał następujące zalety dzieła Stryjkowskiego:

1. jako pierwszy podjął się napisania historii Litwy i Rusi - ,jemu winniśmy, cokolwiek mamy wiadomości o dziejach tych państw obszernych";

2. korzystał z „najrzadszych autorów” i latopisów ruskich, ratując dla potomności czyny, a nawet imiona „sławnych bohaterów” tych dziejów;

3. ze swych źródeł korzystał krytycznie, mądrze, „nie na oślep”: ,gruntownie roztrząsa, który z nich doskonalej prawdy dowodzi, a omyłki w nich postrzeżone rozsądną krytyką odkrywa i poprawia"95.

Przedruk jest wierny, znacznemu ograniczeniu uległy jedynie marginalia - w dużej mierze całkiem opuszczone, czasem podlegające jedynie skróceniu ${ }^{96}$. Na nowo sporządzono indeks, który jest też znacznie krótszy i zawiera przede wszystkim odsyłacze do osób (choć odnajdujemy również Chio wysep, Czarne Morze czy Czechowie chrzest przyjęli). Jezuiccy edytorzy uwzględnili również niektóre poprawki z erraty, choć nie wszystkie $^{97}$. Co jednak ważniejsze, nie nastapiły jakiekolwiek zmiany we

93 Szerzej o tym J. Kurkowski, Dyskusja J. A. Jabłonowskiego z J. A. Załuskim o wartości i zadaniach polskiej historiografii, „Analecta. Studia i Materiały z Dziejów Nauki", 8:1999, nr 1, s. 15-58.

94 Przedmowa ks. Franciszka Bohomolca Societatis Jesu do tomu drugiego Zbioru dziejopisów polskich, Warszawa 1766.

95 Tamże.

96 Edycja 1582, s. 6: „Noe naprzód wynalazł wino i sam się nim pierwej upił”; edycja 1766, s. 7: „Noe naprzód wynalazł wino”.

97 Edycja z 1582, s. 406: „Olgier”; edycja 1766, s. 363: „Olgierd”; ale według erraty „Kożuchów” miał być słusznie zastapiony przez „Wschowę” (Freistadt), jednak nie jest (edycja 1582 - s. 62; edycja 1766 - s. 69). 
fragmentach, które przedstawiają moskiewskie zbrodnie, wiarołomstwo, brak odwagi żołnierzy, „,zwyczajne bajki” tamtejszych posłów itd. Trzeba przy tym pamiętać, że tom pierwszy Zbioru zadedykowano Stanisławowi Augustowi (tom drugi - bratu króla, Kazimierzowi Poniatowskiemu), a publikacja nastapiła w pierwszym okresie jego panowania, związanym ze znacznym wzrostem kontroli rosyjskiej nad życiem publicznym Rzeczypospolitej. Tymczasem, jak zauważa Janusz Tazbir, cenzura rosyjska w XVIII w. doprowadziła nawet do zniszczenia pewnych wydawnictw historycznych ukazujących dawne tryumfy Polski nad Moskwą. Już od połowy XVII w. poselstwa moskiewskie zatrudniały osoby, które właśnie pod tym kątem przeglądały polskie kroniki i poematy historyczne, zarówno drukowane, jak i krązące $\mathrm{w}$ odpisach ${ }^{98}$. Z drugiej strony trzeba zwrócić uwagę, że Kronikę Stryjkowskiego przetłumaczono na rosyjski aż czterokrotnie w ciagu zaledwie dwóch dziesięcioleci XVII w. (16681688), a fakt zachowania w rosyjskich zbiorach aż dziesięciu rękopisów wersji z roku 1688 dowodzi popularności dzieła ${ }^{99}$.

Edytorzy Zbioru dziejopisów polskich uznali za konieczne uzupełnić dane historyczne Stryjkowskiego jedynie w zakresie dziejów Rosji. Prefekt drukarni, F. Bohomolec, czuł się w obowiązku, aby wytłumaczyć się z tego nieco zaskakującego rozstrzygnięcia. Pisał w Przedmowie: „Nie powinna by wprawdzie historia rossyjska mieścić się w Zbiorze historyków polskich, położyłem ją jednak dlatego, iż wielce służy do objaśnienia historii litewskiej i Rusi do nas należącej". Jako ów appendix wybrano opracowanie francuskiego autora Jacquesa Lacombe'a (17241811), zatytułowane Histoire des révolutions de l'Empire de Russie, które w 1760 roku ukazało się w Paryżu i w Amsterdamie. W 1761 roku Immanuel M. Kästner przetłumaczył je na niemiecki i opublikował w Lipsku ${ }^{100}$. Wspomniany już wyżej w przeglądzie osiemnastowiecznych dzieł francuskich o dziejach Rosji Lacombe reprezentuje tzw. kronikarski nurt historiografii. Z wykształcenia prawnik, z zawodu księgarz, drukarz, wydawca (także czasopism, np. od 1768 r. wydawał „Mercure de France”) zwolennik „filozofów”, korespondent Woltera (którego ów nazywał swym przyjacielem), w latach 60. trudnił się także kompilowaniem dzieł historycznych ${ }^{101}$. Te publikacje cieszyły się sporym powodzeniem, a kompila-

98 J. Tazbir, Rosjanie w literaturze..., s. 252.

99 Na podstawie badań A. I. Rogowa H.-J. Bömelburg, dz. cyt., s. 600.

${ }^{100}$ Geschichte der Staats-Veränderungen im Russischen Reiche, Leipzig1761.

101 J. Sgard, Jacques Lacombe (1724-1811), [w:] Dictionnaire des journalistes, $<$ http://dictionnaire-journalistes.gazettes $18 \mathrm{e}$.fr/journaliste/437-jacques-lacombe $>$ (słownik pod opieką Voltaire Foundation). Po bankructwie w 1778 r. Lacombe zajmował się redagowaniem licznych «dictionnaires» de l'Encyclopédie méthodique. 
cję dziejów Rosji ze względu na wartość informacyjną polecał sam Wolter - autor sławnych dzieł o czasach Karola XII i Piotra I ${ }^{102}$. Lacombe, sam korzystając obficie z literatury, nie dbał zbytnio o prawa autorskie: Jean Jacques Rousseau oskarżał go o plagiat (,słowo w słowo") swych muzycznych tekstów z Wielkiej encyklopedii w opublikowanej w 1752 r. encyklopedii sztuki pt. Dictionnaire portatif des beaux-arts, ou Abrégé de ce qui concerne l'architecture, la sculpture, la peinture, la gravure, la poésie et la musique $e^{103}$.

Opracowanie Lacombe'a podkreśla wyjątkowość państwa rosyjskiego i rosyjskich dziejów. Oto fragment rozpoczynający Przedmowę w thumaczeniu Grzegorza Kniażewicza (1737-1804): „Chociaż nie ma państwa na świecie, w którym by nie zachodziły odmiany, żadne jednak tak nadzwyczajnych, tak nagłych i licznych jako Moskwa nie doświadczyło. Dzieje te mogłyby za bajkę być poczytane, gdyby nie były stwierdzonej czasu niedawnością i samych dzieł sprawców życiem pamięci naszej sięgającym"104. Autor zaznacza także, iż Rosja to największy kraj na świecie, zajmujący północ Azji i Europy. Jego mieszkańcy przez Europejczyków długo ,za dzicz podobną amerykańskiej byli miani”, a „rządy całe na wypędzeniu z Rossyi nauk, rzemiosł i najprostszych umiejętności zasadzały się"105. Lacombe prezentuje jednak tradycyjne faktograficzne ujęcie dziejów, koncentrując swą uwagę na wojnach, dowódcach, zabiegach dyplomatycznych, niepokojach wewnętrznych, przewrotach pałacowych itp. Jest przy tym ostrożny w zagłębianiu się w mityczne dzieje: opierając się na sprawdzonej faktografii, swą narrację rozpoczyna dopiero od 976 roku. W sprawie genealogii Rosjan wypowiada się powściagliwie. Powołuje się na powszechne mniemanie, iż mają rodowód słowiański, a Słowianie z kolei wywodzą się od Scytów. Początki ich państwowości datuje zaś na szósty wiek po narodzeniu Chrystusa ${ }^{106}$. Kwestie życia umy-

102 Oeuvres complètes de Voltaire, t. 1, Études et documents biographiques. Nouvelle édition, Paris 1883, s. 351.

103 J. Sgard, dz. cyt.

104 J. Lacombe, Historia odmian zaszłych w państwie rosyjskim, tłum. G. Kniażewicz, Warszawa 1766. Wersja francuska brzmi: „Il n'y a point d'états qui n'ayent eu leurs révolutions; mais aucun n'en présente d'aussi extraordinaires, d'aussi rapides, et d'aussi multipliées que la Russie. Cette histoire passeroit pour une fable, si les faits les plus singuliers n'étoient point de ce siècle, et si le héros qui en forme le principal intérêt n'avoit été notre contemporain". J. Lacombe, Histoire des révolutions de l'empire de Russie, Amsterdam 1760, Avertissement, s. III.

105 J. Lacombe, Historia odmian..., s. 3, 4. W wersji francuskojęzycznej: „Les peuples de cet Empire ont été long-temps regardés par le reste de l'Europe comme des sauvages d'un autre monde..."; „La politique s'attachoit à proscrire de la Russie les sciences, les arts, et les plus simples connoissances", J. Lacombe, Histoire ..., s. 2, 3.

106 J. Lacombe, Historia odmian..., s. 4; tenże, Histoire ..., s. 6. 
słowego, społecznego czy gospodarczego w Rosji są krótko odnotowane, przede wszystkim na kanwie owej wielkiej „odmiany” dokonanej przez Piotra $\mathrm{I}^{107}$. W ocenie działań tego władcy autor jest zreszta niezwykle wyrozumiały, co widać choćby w relacji o śmierci następcy tronu Aleksego: „Tak Piotr Wielki uczynił ofiarę z syna swego, ostatniego obrońcy dzikości moskiewskiej, dla uszczęśliwienia i chwały państwa”. Dostrzega tu, co prawda, intrygi Aleksandra Mienszykowa i Katarzyny, które „pobudziły go jako mściwego i okrutnego do rozlania krwi syna”, a także zgubny wpływ na Aleksego „bałwochwalstwa starych moskiewskiej zabobonności sług"108. Podobnie Wolter usprawiedliwiał ów czyn interesem 18 milionów mieszkańców kraju oraz surowymi prawami i obyczajami panującymi w Rosji, a nielojalność Aleksego wiązał z Cerkwią - z wpływem popów i mnichów, będącym źródłem wielu nieszczęść ${ }^{109}$. Kronikarska wersja dziejów Rosji Lacombe'a przez swą apologetyczność wobec władców nowej Rosji niekiedy zbliża się więc do ujęć „filozofów”, choć zdecydowanie brak jej wyrazistości i wszechobecności publicystycznych rozważań, a przede wszystkim ambicji historiozoficznych - jak w przypadku Wolterowskiej racjonalistycznej koncepcji historii jako dziejów cywilizacji ${ }^{110}$. W obu jednak przypadkach mamy prosty biało-czarny schemat: „barbarzyństwo” dawnej Moskwy stanowi pożądany kontrast dla zeuropeizowanej nowej Rosji. Tak więc w uwagach o rzeczywistym „cywilizowaniu się” Rosji i rozwoju manufaktur już w czasach Piotra bez trudu odnajdujemy analogie do opisu Woltera ${ }^{111}$. Mimo to nie Wolter był głównym źródłem Lacombe'a, lecz Éléazar de Mauvillon (1712-1779), filolog, historyk i tłumacz, przez pewien czas podobno sekretarz prywatny Fryderyka Augusta Wettyna, króla polskiego Augusta II (czy raczej Augusta III), następnie profesor języka francuskiego na uniwersytecie

107 Zob. J. Lacombe, Historia odmian..., s. 112; tenże, Histoire ..., s. 342-343.

108 J. Lacombe, Historia odmian..., s. 103, 105; tenże, Histoire ..., s. 311-312: ,il étoit entretenu dans cette espèce d'idolâtrie par les vieux partisans de la barbarie Moscovite"; s. 321: „Pierre Le Grand venoit de faire le sacrifice de son fils, et des derniers partisans de la barbarie Moscovite au soutien de sa glorie et à l'intérêt de ses états" (a więc w wersji francuskojęzycznej jest mowa o dbałości Piotra o swoją „,chwałę” i interes państwa).

109 I. Hanslik, dz. cyt. s. 166 (,Aber Voltaire entschuldigt alles mit dem Guten, das der Zar für sein Volk getan habe"), 173-174. Por. F.-M. Arouet (Voltaire), Histoire de l'Empire de Russie sous Pierre le Grand, t. 2, Genève 1763, s. 139-189.

110 E. A. Mierzwa, Historia historiografii, t. 2, Warszawa 2007, s. 535-536. Co prawda, Histoire de l'Empire de Russie sous Pierre le Grand nie reprezentuje takiego historiozoficznego poziomu jak Siècle de Louis XIV czy L'essai sur les moeurs et l'esprit des nations.

111 I. Hanslik, dz. cyt., s. 181. Zob. F.-M. Arouet (Voltaire), dz. cyt., t. 1, Genève 1759, np. s. 211-213, t. 2, Genève 1763, s. 190-197. 
lipskim, a wreszcie w Collegium Carolinum w Brunszwiku ${ }^{112}$. W $1742 \mathrm{r}$. Mauvillon opublikował Histoire de Pierre I surnommé le Grand, empereur de toutes les Russies i stąd właśnie Lacombe zaczerpnął wiele informacji i sądów, jak np. ogólną ocenę postaci Piotra $\mathrm{I}^{113}$. Przegląd dziejów Rosji został doprowadzony przez Lacombe'a do roku 1743, a więc czasów panowania cesarzowej Elżbiety. Francuski autor podkreśla zgodność pałacowego przewrotu z testamentową wolą Piotra Wielkiego, jak i to, że „wszyscy uznali w jej pretensjach sprawiedliwość”, a późniejsze „wszystkie rozporządzenia sławiły w Elżbiecie Heroinę ludzkości, Dobrodzijkę nauk i Dziedziczkę potęgi a chwały Piotra Wielkiego prawdziwą"114. Pamiętajmy, iż tłem publikacji dzieła jest wojna siedmioletnia jeszcze za życia Elżbiety, a więc w fazie zwycięskiego pochodu armii rosyjskiej (która np. 12 sierpnia 1759 r. odniosła wielkie zwycięstwo pod Kunowicami) - koalicjanta Francji.

Kolejną część uzupełnień odnoszących się do dziejów Rosji w Zbiorze dziejopisów polskich stanowią ks. Karola Wyrwicza Soc. Jesu Rektora Coll. Nob. Warszawskiego Uwagi nad historiq odmian w państwie rosyjskim przez Jakuba Lacombe po francusku napisana na polski język przettumaczona. Karol Wyrwicz (1717-1793) rozpoczyna swoje uwagi od refleksji nad rozkwitem i upadkiem kultur, począwszy od antycznej Grecji i Rzymu poprzez imperium Arabów, którzy ,umorzone w Europie ożywili nauki", aż po mocarstwa europejskie - Wenecję, a zwłaszcza Francję, która „gdy pod doskonałe jedynowładztwo powróciła, w nauki i handle tak zakwitnęła, że temi czasy poloru nauk, obyczajności, przemysłu stała się szkołą"115. Rektor Collegium Nobilium dostrzega także niezwykły progres „w męstwie i polorze” w krajach sąsiadujących z Rzeczpospolitą. Wśród nich wyjątkowe zmiany dokonały się właśnie w Rosji, co Wyrwicz objaśnia następująco: „Opatrzność państwa sprawująca i chwałę z jednego narodu do drugiego przenosząca dała na

112 Zob. J.-M. Quérard, La France littéraire ou Dictionnaire bibliographique des savants, historiens et gens de lettres de la France, ainsi que des littérateurs étrangers qui ont écrit en français, plus particulièrement pendant les XVIIIe et XIXe siècles, t. 5, Paris 1833; Patrimoine littéraire européen. Index général, red. J. C. Polet, Bruxelles 2000, s. 478 (Répertoire des traducteurs). W chwili śmierci Fryderyka Augusta I (Augusta II) Mauvillon miał dopiero 20 lat. Ze wzmianki w Histoire du Prince François Eugène de Savoie, généralissime des armées de l'Empereur et de l'Empire (t. 1, Amsterdam-Leipzig 1740) wynikałoby, że wychował się we Francji, a w Rzeszy jest od kilku lat (zob. tam Lettre l'auteur aux librairies).

113 I. Hanslik, dz. cyt., s. 180-182.

114 Zob. J. Lacombe, Historia odmian..., s. 118, 120; tenże, Histoire ..., s. 359 („On reconnut la légimité de ses droits"), 366.

115 Karola Wyrwicza... Uwagi..., [w:] J. Lacombe, Historia odmian..., s. 121-122. 
schyłku wieku przeszłego Moskalom monarchę w osobie Piotra I, który obszerniejszym niż rozległe jego państwa od szczęśliwego przyrodzenia obdarzony rozumem i wielkością umysłu ani przeciwnościami, ani trudnościami nieustraszonego, naród swój z grubości otarł, obyczajność wprowadził, nauki zaszczepił, cudzoziemcom do Moskwy, Moskalom do cudzych krajów zamknięte granice otworzył”. Ów stan izolacji i „,barbarzyństwa” powodował, że przed czasami Piotra I „dziejów swych do następnych wieków wiadomości podać nie umieli” i w rezultacie „ledwie jedna abo dwie niedokładne i omyłkami poszpecone znajdują się w ojczystym języku kroniki”. Zdaniem autora ,żadnego w Europie nie masz narodu, który by tak mało miał dziejopisów czy to domowych, czy obcych jak Moskwa. Historycy polscy i szwedzcy nie wchodząc w głębokie poznanie obyczajów, praw i rząów moskiewskich, na tym tylko przestawali, że wojny i przymierza pokoju z Moskalami opisali. Poselstwa cesarzów rzymskich i niektórych królów do carów moskiewskich wysłane dały Europie stan Moskwy choć niedoskonale poznać"116. Wyrwicz uznaje więc za konieczne sporządzenie wykazu „tych wszystkich [..], którzy o Moskwie jakimkolwiek językiem i z jakiegokolwiek narodu pisali”. Warto przyjrzeć się temu zestawieniu Pisarzy dziejów moskiewskich, bowiem to pierwsza ogólna kwerenda bibliograficzna i źródłoznawcza na temat historii wschodniego sassiada w kulturze umysłowej Rzeczypospolitej XVIII w. I tutaj punktem odniesienia jest literatura francuska, ale Nicolas Lenglet du Fresnoy (1674-1755) w sławnym dziele Méthode pour étudier l'histoire potrafił wyliczyć zaledwie „kilka” takich pozycji ${ }^{117}$. W wydaniu pierwszym z $1713 \mathrm{r}$. w tomie pierwszym rzeczywiście jest ich niewiele: nie uwzględniając wydań zbiorowych, naliczyć można ich tylko osiem. Odnajdujemy tam jeszcze informację, że o Kościele prawosławnym obok rozpraw Antonia Possevina (1533-1611), Jana Łasickiego (1534-1602) $)^{118}$ i Johanna Ernsta Gerharda (1621-

116 Tamże, s. 123.

117 Zdaniem Jerzego Topolskiego jest to najwybitniejsza historyka opublikowana przed XIX stuleciem. O jej europejskim oddziaływaniu świadczą liczne wydania, także w thumaczeniu niemieckim (Lipsk 1714 i 1718, potem Gotha 1752 i 1754) czy angielskim (Londyn 1728 i 1730). Ostatnie wydanie w XVIII w. miało miejsce w Paryżu w 1772 r. - J. Topolski, Historia profana i historia sacra. Nicolas Lenglet du Fresnoy (1674-1755) i jego metoda dochodzenia do prawdy historycznej, [w:] tegoż, Prawda i model $w$ historiografii, Łódź 1983, s. 75, 84-86. Warto dodać, że Maciej Dogiel podczas swego pobytu w Paryżu w 1745/46 r. poznał osobiście Lengleta du Fresnoya i jego zbiory. Zob. J. D. Janocki, Lexicon derer iztlebenden Gelehrten in Polen, t. 1, Breslau 1755, s. 30; J. Kurkowski, Z dziejów polskiego edytorstwa..., s. 101.

118 J. Łasicki, De Russorum, Moscovitorum et Tartarorum religione, Spirae 1582. 
1668) ${ }^{119}$ jest jeszcze kilka innych godnych uwagi, które zostały wymienione na końcu książki w katalogu dzieł wydanych przez oficynę Jeana Musiera. W tomie drugim powtarza się właściwie ten sam zestaw (poza wzmianką o Gerhardzie) ${ }^{120}$. W wydaniu kolejnym, uzupełnionym (Paryż 1729) zamieszczono nieco więcej, bo 17 pozycji ${ }^{121}$. Nadal jednak na bibliografię dziejów wielkiego państwa to niezwykle mało.

Wyrwicz prezentuje w układzie chronologicznym (,latopisarskim porządkiem") około 60 rękopisów i druków począwszy od 1110 do 1760 r., a więc do momentu publikacji dzieła Woltera o Piotrze I (faktycznie druk pierwszego wydania nastapił w 1759 r.) i opracowania dziejów Rosji autorstwa Lacombe'a. W zgodzie z podaną wcześniej informacją rękopiśmienne źródła do dawnych dziejów moskiewskich zajmują tu niewiele miejsca. Wykaz otwiera ,pierwszy kronikarz ruski” Teodozy „,mnich pieczarski klasztoru s. Michała ilhumen”. Z notatki Wyrwicza dowiadujemy się, że ów mnich urodził się w 1034 r., żył około 80 lat, zaś rękopis obejmuje okres do 1206 r., a więc musiał być kontynuowany przez nieznanego z imienia następcę. Podkreśla także, iż ów Teodozy nie jest tożsamy ze świętym Teodozym Pieczerskim (ok. 1008-1074). Ta bałamutna informacja wywodzi się zapewne z niemieckiego thumaczenia Gerharda Friedricha Müllera (1705-1783) tekstu rzekomego mnicha Teodozego, który opublikowano w „Sammlung russischer Geschichte”. Pod rokiem 1732 znajdujemy zresztą w wykazie Wyrwicza wystarczający na to dowód: „Gerard Fryderyk Muller nauczyciel historii w Akademii petersburskiej wydał po niemiecku Zebranie dziet [sic!] Ruskich r. 1732 i 1733 w Petersburgu 3 części in 8 . Miller wyłożył na język niemiecki kronikę pisaną po słoweńsku Teodozego ilhumena kijowskiego"122. Zeszyt pierwszy tomu pierwszego tego periodyku otwiera Nachricht von einem alten mst. der russischen Geschichte des Abtes Theodosii von Kiow. Tam odnajdujemy informację o datach urodzenia Teodozego i wstapienia do Ławry Pieczerskiej, a także o tym, że mógł on doprowadzić dzieje do około $1120 \mathrm{r}$. (Wyrwicz stwierdza: „do roku 1110 abo trochę dalej") ${ }^{123}$. Potem następuje nie thumaczenie całości, ale wyciąg z tekstu („Auszug”), który ciąnnie się przez kolejne sześć zeszytów tego tomu. Jak wynika z przytoczonego powyżej cytatu, Wyrwicz znał tylko trzy pierwsze z nich. Nie mógł więc

119 J. E. Gerhard, Цурковь Московскій, sive dissertatio theologica de religione ritibusque ecclesiasticis Moscovitarum, Revaliae także Jenae 1720.

120 N. Lenglet du Fresnoy, Méthode..., Paris 1713, s. 309.

121 N. Lenglet du Fresnoy, Méthode..., Paris 1729, s. 384-385. s. 132 .

122 K. Wyrwicz, Pisarze dziejów moskiewskich, [w:] J. Lacombe, Historia odmian...,

${ }^{123}$ „Sammlung russischer Geschichte”, t. 1, z. 1, Petersburg 1732, s. 1-3. 
wiedzieć, że w tomie piątym „Sammlung”, opublikowanym w 1760 r., Müller przyznał się do błędu w przypisaniu autorstwa Teodozemu - nie był w stanie wówczas sam czytać staroruskich tekstów i musiał korzystać z thumacza, który okazał się nieudolny ${ }^{124}$. Tymczasem tekst ten to pierwsza część Powieści dorocznej Nestora i jego bezpośredniego następcy. Wady opublikowanego ekstraktu nie dotyczą jedynie kwestii autorstwa, dlatego należałoby „einen neuen Auszug [...] zu verfertigen” ${ }^{25}$. Artykuł Versuch einer neueren Geschichte von Russland poświęcony jest sprawie kontynuacji pozostającego wówczas jeszcze w rękopisie dzieła Wasilija Tatiszczewa История Российская с самых древнейших времён, doprowadzonego do czasów Fiodora I. Tak więc informacja Wyrwicza dubluje de facto trzeci opis poświęcony właśnie ,starodawnemu latopiscy ruskiemu", Nestorowi.

Drugą pozycję w wykazie Pisarzy dziejów moskiewiskich zajmuje Symon (Szymon) biskup suzdalski, ,który pisał życie ojców pieczarskich”. Chodzi tu chyba o sławny Pateryk Kijowsko-Pieczerski, choć wzmianka jest bardzo lakoniczna. Dodać trzeba, że Wyrwicz zna dość swobodny przekład tego tekstu na język polski w redakcji Kasjana z 1462 r. (tzw. drugiej), dokonany przez prawosławnego biskupa mścisławskiego, orszańskiego i mohylewskiego Sylwestra Kossowa i opublikowany w Kijowie w 1635 r. pt. Paterikon, albo żywoty ss. Ojców Pieczarskich. Tłumaczenie Kossowa uzupełnione zostało komentarzem oraz „Chronologia o prawosławnych metropolitach ruskich” doprowadzoną do - 46 w kolejności - Piotra Mohyły. Ta edycja, mimo że niezbyt wierna oryginałowi i stanowiąca jedynie piętnastowieczny wariant tekstu, stała się później podstawą thumaczeń na język rosyjski i ukraiński ${ }^{126}$. Wyrwicz zgodnie z tytułem tłumaczenia Kossowa przypisuje autorstwo utworu św. Nestorowi i zaznacza, iż jest to wersja skrócona ${ }^{127}$.

Kolejne źródło do dziejów Rosji to sławna Stiepiennaja kniga (Книгa Степенная иарского родословия), szesnastowieczny rękopiśmienny zabytek literatury rosyjskiej będący świadectwem dążenia ówczesnej elity politycznej do uporządkowania i ukierunkowania obrazu dziejów moskiewskich, powstały w kręgu metropolity Makarego. Pierwsza pu-

${ }^{124}$ Czyżby był to A.B. Sellius? Zob. poniżej.

125 „Sammlung russischer Geschichte”, t. 5, z. 1-2, Petersburg 1760, s. 6-7.

126 L. Nodzyńska, Opracowanie, [w:] Pateryk Kijowsko-Pieczerski, czyli opowieści o świętych ojcach $w$ pieczarach kijowskich położonych, Wrocław 1993, s. 55-56. Dzieło Kossowa służyć miało jako argument w konflikcie wokół unii brzeskiej - jako uzasadnienie całkowitej odrębności ruskiego chrześcijaństwa od Rzymu.

127 K. Wyrwicz, Pisarze dziejów moskiewskich, [w:] J. Lacombe, Historia odmian..., s. $126-127$. 
blikacja nastapiła już po edycji Zbioru dziejopisów polskich - w dwóch tomach wydanych w Moskwie w 1775 r. „под смотрением” G. F. Müllera. Wpływ tego tekstu na historiografię rosyjską XVII-XVIII w. stanowi od lat temat naukowych sporów, niedawno także (2007-2011) doszło do krytycznej edycji jego całości przez zespół pod kierunkiem Nikołaja N. Pokrowskiego (podstawa jest znaleziony przez Pokrowskiego tzw. Томский список) $)^{128}$. Wyrwicz o istnieniu tego źródła wie z literatury francuskiej. Podkreśla, że chronologia i ,pochodzenie książąt mają być w niej dokładne, ale dzieł wiele znajduje się bajecznych". Informatorem jest wspomniany już J. N. Delisle, który, ,przez długi czas w Petersburgu mieszkając”, wybrał z niej „pewniejsze dzieje” i chronologię władców (zob. poniżej) ${ }^{129}$.

Rektor jezuickiego Collegium Nobilium nie zna natomiast podstawowej pomocy bibliograficznej do dziejów Rosji, a mianowicie zestawienia Duńczyka Adama Burcharda Selliusa (1695-1745) opublikowanego w Tallinie w 1736 r. pt. Schediasma litterarium de scriptoribus, qui historiam politico-ecclesiasticam Rossiae scriptis illustrarunt. Interesująca biografia tego autora jest pełna niejasności, warto więc nieco ją przybliżyć na podstawie niedawnych wyników badań ${ }^{130}$. Związany z pietyzmem Sellius pojawił się w Rosji około 1722 r. jako nauczyciel łaciny w jednej ze szkół Petersburga. W 1725 r. przeniósł się do Moskwy, a następnie opuścił Rosję i usiłował zdobyć stanowisko na uniwersytecie w Kilonii. Powrót nastapił w 1732 r. Sellius podjął starania o posadę w petersburskiej Akademii Nauk i Sztuk Pięknych uwieńczone stanowiskiem tłumacza z niemieckiego i na niemiecki. W Akademii bliżej zaprzyjaźnił się z historykiem i orientalistą Gottliebem Siegfriedem Bayerem (16941738). Wtedy także rozpoczął prace nad Schediasma litterarium (ukończone w 1735 r.), mając nadzieję na publikację dzieła przez Akademię. $\mathrm{Z}$ nieznanych powodów do tego nie doszło, być może po prostu dlatego, że Sellius przestał być tam zatrudniony (niewykluczone w tej sprawie są także problemy z cenzura). Do 1736 r. uczył łaciny i greki w seminarium

${ }^{128} \mathrm{Z}$ nowszej literatury zob. А. В. Сиренов, Степенная книга и русская историческая мысль XVI-XVIII вв, Petersburg 2010.

${ }_{129}$ Karola Wyrwicza... Uwagi..., [w:] J. Lacombe, Historia odmian..., s. 124.

130 Informacje o życiorysie urodzonego w Szlezwik-Holsztynie Selliusa są bardzo rozbieżne. Zob. P. Strahl, Das gelehrte Russland, Leippzig 1828, s. 375-379; А. Бороздин, Селлий Б.А., Русский биографический словарь, t. XVIII, Petersburg 1904, s. $292-$ 293; Б. Титлинов(?), Никодим (в миру Адам Бурхард Селий-иеромонах), Русский биографический словарь, t. XI, Petersburg 1914, s. 343-344. Rozbieżności i watpliwości w biografii Selliusa analizują C. L. Drage i J. Sullivan: Adam Burchardt Sellius and „Zertsalo istoricheskoe gosudarei rossiiskikh”, „The Slavonic and East European Review", 70:1992, nr 4, s. 601-614. 
Aleksandra Newskiego w Petersburgu, potem przeniósł się do Moskwy, gdzie zbierać miał materiały do historii Rosji, a w latach 1741-1742 thumaczyć na niemiecki latopisy ruskie. Tylko w wersji rosyjskojęzycznej zachowały się jego wiersze pisane pierwotnie po łacinie jako mnemotechniczna pomoc do nauki historii od Ruryka do cesarzowej Elżbiety (Зериало историческое государей российских). Zajmował się także dziejami Cerkwi (De Rossorum Hierarchia libri quinque), przeszedł zresztą oficjalnie na prawosławie (1744) i swój żywot zakończył w klasztorze jako mnich o imieniu Nikodem.

Schediasma Selliusa to dzieło o wielkim znaczeniu dla rozwoju rosyjskiej historiografii: jest to druga drukowana książka na temat historii politycznej i kościelnej, a zarazem pierwsza bibliografia ${ }^{131}$, co więcej opublikowana w języku międzynarodowym. Gromadzi informacje o dziełach 164 autorów i 50 anonimowych tekstach, a więc bez porównania więcej niż późniejszy o 30 lat wykaz Wyrwicza. Dla okresu do 1736 r. Sellius nie notuje 17 pozycji znanych Wyrwiczowi. Najwidoczniej nie zna jeszcze publikacji Woltera o Karolu XII, jak też łatwo się domyślić - brak mu informacji o pewnych polskich publikacjach (np. o wspomnianym wyżej dziele Sylwestra Kossowa, Atanazego Kalnofoyskiego o monastyrze pieczerskim, nagrobkach i fundatorach spośród „książąt moskiewskich, jako panów polskich i moskiewskich", rękopisie arcybiskupa Jana Łaskiego „Delatio de erroribus Moschorum facta in concillio Lateranensi” 132 czy o dwóch pierwszych Klimakterach Wespazjana Kochowskiego). Niektóre publikacje włączone do zestawienia Wyrwicza wnoszą bardzo niewiele do poznania dziejów moskiewskich. Wyrazistym przykładem jest Gynaeceum, sive Theatrum mulierum, in quo praecipuarum omnium per Europam in primis nationum... fomineos habitus videre est, artificiosissimis nunc primum figuris... expressos (Frankfurt 1586) Josta Ammanna (1539-1591), gdzie znajdować się miałyby ,wiadomości o odzieniu białych głów moskiewskich, onych wychowaniu, zamęściu, obcowaniu etc." ${ }^{133}$. W rzeczywistości obok jedynej ryciny (zatyt. Moscovica foemina primaria) odnajdujemy tam kilka ogólnikowych uwag w paru dosłownie zdaniach ${ }^{134}$. Nic dziwnego, że Sellius takich publikacji nie uwzględnia,

131 C. L. Drage, J. Sullivan, dz. cyt., s. 615.

${ }^{132}$ Karola Wyrwicza... Uwagi..., [w:] J.Lacombe, Historiaodmian..., s. 124. Informacja o tym rękopisie z archiwum gnieźnieńskiego pochodzić miała z Annales ecclesiastici. O wypowiedzi Jana Łaskiego na Soborze Laterańskim V na temat prawosławia zob. Annales ecclesiastici ab anno quo desinit Card. Caes. Baronius M.C.XCVIII usque ad annum M.D.XXXIV. continuati, t. 22, Coloniae Agrippinae 1694, s. 180.

133 Karola Wyrwicza... Uwagi..., [w:] J. Lacombe, Historia odmian..., s. 125.

134 Zob. s. 109. Całość tego tekstu brzmi następująco: „Moscovicis mos est vestem 
choć trzeba zauważyć, że ma on jednak pewne kłopoty także z dawniejszą literaturą zachodnioeuropejską ${ }^{135}$. Co ciekawe, nie zna (lub ją pomija) omówionej powyżej relacji Foy de la Neuville'a (Adriena Bailleta). Obie bibliografie reprezentuja adnotowany typ, w opisach występują uwagi o wartości zestawionych dzieł, choć oczywiście zestawienie polskiego jezuity jest znacznie bardziej skrótowe ${ }^{136}$. Najwyższą ocenę Wyrwicz przyznał dziełu Jeana Rousseta de Missy, przetłumaczonemu kilkanaście lat później na język polski przez Bernarda Syrucia. Sporo uwagi jezuita poświęcił też publikacjom petersburskiej Akademii, które ceni, choć dostrzega też błędy. Jako przykład przytacza tu sąd jednego z pierwszych akademików Gottlieba Siegfrieda Bayera o pochodzeniu nazwy Moskali ${ }^{137}$.

Chronologiczny spis władców „ruskich” następujący po zestawieniu bibliograficznym Wyrwicza pochodzi, jak już wspomniano, z wypisów J. N. Delisle'a ze Stiepiennoj knigi - o czym nadmienia sam autor Uwag. Odnalezienie podstawy nie jest łatwe, bowiem takiego spisu nie ma wśród publikacji sławnego astronoma i kartografa. Został bowiem włączony do czterotomowego dzieła francuskiego orientalisty Josepha de Guignesa (1721-1800), które ukazało się w Paryżu w latach 1756-1758 pt. Histoire générale des Huns, des Turcs, des Mogols, et des autres Tartares occidentaux $^{138}$. De Guignes studiował języki i badał kultury orientalne (jego zainteresowania koncentrowały się na Chinach), w Bibliotece Królewskiej pracował jako specjalista od języków wschodnich, a od 1757 r.

hanc gestare puellis/Quarum iam puppas dextera Cypris habet/Pellita in qua quod sunt pleraque sic rigor orbis/Illius, et Borea subdita regna iubent/Caetera, colligere est quod de praesente figura/Grata satis merito commoditate sua est./Commoditate, aio? Imò et majestate decora est,/Qualem vix simile Gallia culta dabit." Nieco dalej mamy rycinę pt. „Fœmina peruviana” (s. 112), jest więc w tym przedstawieniu klimat egzotyki.

${ }^{135}$ Brak tam np. L. Assarino (1607?-1672), König Demetrius. Eine warhaffte, aber mit vielen Sinnreichen, zur Wolredenheit, Lesen-Anmutigheit, auch nutzlicher Sittenlehre dienlichen Beygedichten vermehrte und geschmükkte Geschicht, Nürnberg 1653 (Wyrwicz odnotowuje wersję włoska, francuską i holenderska); Il Demetrio Moscovita historia tragica del conte Maiolino Bisaccioni, t. 1, Roma 1643; t. 2, Venezia 1649 - zob. Karola Wyrwicza... Uwagi..., [w:] J. Lacombe, Historia odmian..., s. 127.

136 Wyrwicz np. wysoko ocenia krótki tekst sławnego poety i pisarza angielskiego Johna Miltona (1608-1674) A Brief History of Moscovia - London 1682 (zob. s. 128). Sellius tej publikacji nie zna. Jezuita klasyfikuje także kolejne wydania, np. o relacji A. Possevina dowiadujemy się, że najbardziej wartościowa jest jej edycja kolońska (zob. s. 125).

137 Karola Wyrwicza... Uwagi..., [w:] J. Lacombe, Historia odmian..., s. 130-131. „Nie wiem komu może podobać się to jego o nazwisku Moskalów zdanie: Moskwa, mówi, jest tak nazwana od klasztoru męskiego, który był nazwany Muskoj. Nim wiara chrześcijańska i klasztory w Moskwie były, Ruś nazywała się Moskwą".

138 O De Guignesie i jego dziele zob. D. C. Allen, The Predecessors of Champollion, „Proceedings of the American Philosophical Society” 104:1960, nr 5, s. 536-540; J. G. A. Pocock, Barbarism and Religion, Vol. 4: Barbarians, Savages and Empires, zwłaszcza część II: Joseph de Guignes and the Discovery of Eurasia (s. 99-157). 
jako profesor syrologii w Collège royal. Kolejne publikacje przyniosły mu rozgłos i członkostwo w Royal Society (1752) oraz Académie des inscriptions (1754), choć teza o tym, że starożytne Chiny powstały dzięki kolonizacji egipskiej ${ }^{139}$, przy której uparcie obstawał, budziła wiele krytycznych uwag, także ironicznych. Sporo miejsca na ośmieszenie typu wnioskowania zastosowanego przez De Guignesa poświęcił Wolter we wstępie właśnie do Histoire de l'Empire de Russie sous Pierre le Grand $^{140}$. De Guignes w tomie pierwszym swej Historii Hunów... zamieścił Introduction à l'histoire générale des Huns ou tables chronologiques et historiques des princes qui ont régné dans l'Asie. Tam wśród owych Tatarów zachodnich (księga V) odnajdujemy zestawienie Grands ducs de Russie (LXIII), którego pochodzenie autor wyjaśnia następująco: „Celleci est tirée des Annales du pays, dont M. de l'Isle m'avoit communiqué un très-long extrait"141. Porównanie tego zestawienia z Chronologiq abo porzadkiem panowania monarchów ruskich Wyrwicza dowodzi ścisłej ich zależności. Chronologia i kolejność panujących jest ta sama, w obu występuje podział na dwie identyczne części (w polskojęzycznej wersji pod tytułami: Ksiażęta kijowscy oraz Ksiażęta włodzimierscy napotym carowie catej Rusi albo Rossyi). Pewne różnice dotyczą jedynie redakcji krótkich opisów panowania poszczególnych władców, które są miejscami uzupełnione ${ }^{142}$, ale także pozbawione pewnych informacji ${ }^{143}$. Dodatki Wyrwicza, znacznie wzbogacające opisy, stają się bardzo widoczne zwłaszcza od Iwana III Wasilijewicza. Francuska wersja odtąd jest lakoniczna, zapewne dlatego, że tu gdzieś kończy się ekstrakt Delisle'a (Stiepiennaja kniga powstała ok. 1560 roku). Wyrwicz w swych opisach akcentuje niedołężność Fiodora I, zabójstwo pierworodnego syna przez Iwana IV, zdobycie korony przez Borysa Godunowa w wyniku zbrodni, klęskę Wasyla Szujskiego i jego śmierć w niewoli, rozkaz Michała I utopienia Maryny Mniszchówny wraz z synem i wreszcie ,skaranie sromotną śmiercią” Stiepana Razina i rzekomego syna Dymitra przez Aleksego I. „Piotr I Wielki nieśmiertelnej nabywszy sławy umiera d. 28 lutego 1725”. Dalej

139 Podobny pogląd wyrażał już sławny jezuita Athanasius Kircher (1602-1680), zob. D. C. Allen, dz. cyt., s. 533-535.

140 F.-M. Arouet (Voltaire), Histoire de l'Empire de Russie..., t. 1, Genève 1759, s. XVI-XXVII.

141 J. de Guignes, Histoire générale des Huns, des Turcs, des Mogols, et des autres Tartares occidentaux, t. 1, Paris 1756, s. 304.

${ }^{142} \mathrm{~Np}$. o wyprawie na Bułgarię Swiętosława I Zdobywcy, którą Wyrwicz datuje na rok 970. Zob. Karola Wyrwicza... Uwagi..., [w:] J. Lacombe, Historia odmian..., s. 134; J. de Guignes, dz. cyt., s. 305 (brak).

143 Np. o tym, że Wsiewołod I pochowany został w Kijowie (J. de Guignes, dz. cyt., s. 307; Karola Wyrwicza... Uwagi..., [w:] J. Lacombe, Historia odmian..., s. 136). 
Wyrwicz zauważa dramatyczny koniec panowania Iwana VI i Piotra III, który „gdy wielkie czyni zamysły i tron i życie traci”. Hagiograficzny watek pojawia się na zakończenie w odniesieniu do czasów Katarzyny II: „Od wstapienia swego na tron tak chwalebnie rozległym tym rządzi państwem, że Jej ustawy, przedsięwzięcia i prawa są dopełnieniem wielkich dzieł Piotra I, obfitą materią wieków teraźniejszych i przykładem arcymądrego panowania" 144 .

Trzeba dodać, iż jezuicki autor sam nie był wolny od ugruntowanych w Rzeczypospolitej stereotypów na temat Moskali, co więcej, utwierdzał je w swych podręcznikowych publikacjach. Oto opinie zawarte w jego Geografii powszechnej czasów teraźniejszych albo opisaniu krótkim krajów całego świata [...] z najświeższych wiadomości, krajopisarzów, i wędrowników zebranym, ku pożytkowi młodzi narodowej na szkoły publiczne wydanym (Warszawa 1770 [1773]): „Jakie są przymioty narodu moskiewskiego? Moskale niedawno byli grubianie, nieobyczajni, prości, niewierni w dotrzymaniu traktatów i zabobonni. Żyjąc w niewoli pod panami także niewolnikami nie znali ani nauk i kunsztów, ani poznawali swych własnych potrzeb i pożytków. Za Piotra W. prawodawcy tego narodu zaczęli trochę się polerować i z cudzoziemskiemi krajami poznawać. Moskale są wzrostu miernego, mocni, z przyrodzenia podejrzliwi, srodzy, zuchwali w szczęściu, a małego serca w przeciwności, są sposobni do wojny, żyją niekosztownie, wytrzymują wielkie trudy i są ślepo posłuszni swym generałom. Piotr W. ustawicznie ich ćwicząc, a Karol XII król szwedzki nieprzestannie zwyciężając, nauczyli ich wojować z sławą. Jednakże umysł ich ma coś jeszcze niewolniczego i braknie im na tych pobudkach sławy i honoru, które czynią ludźmi wielkiemi"145. Identycznie brzmi ten fragment w Geografii czasów teraźniejszych, albo opisaniu naturalnym i politycznym królestw, państw, stanów wszelakich..., której tom pierwszy opublikowano w drukarni jezuickiej Warszawie w roku $1768^{146}$. Dodajmy, że tom drugi nigdy się nie ukazał, a pierwszy - niewatpliwie m.in. z powodu przytoczonych wyżej opinii - po proteście ambasadora Nikołaja Repnina podobno został wycofany z rynku księgarskiego ${ }^{147}$.

Po prezentacji chronologii władców ,ruskich” Wyrwicz przystępuje do objaśnień i sprostowań informacji Lacombe’a, ,aby ucząca się młódź

\footnotetext{
${ }^{144}$ Karola Wyrwicza... Uwagi..., [w:] J. Lacombe, Historia odmian..., s. 142.

145 Tamże, s. 133-134.

146 T. 1, Warszawa 1768, s. 285.

147 Zob. Bibliografia Karola Estreichera, t. XXXIII Kraków 1939 s. 453, Bibliografia literatury polskiej Nowy Korbut, oprac. E. Aleksandrowska z zespołem, t. 6, cz. 1, Wrszawa 1971, s. 482.
} 
polska dziejów sąsiedzkich w błędy nie wpadła historyczne". Pierwszy powód do polemiki dają uwagi o pochodzeniu Moskali i etymologii nazw Moskal, Rosjanin, Rosja. Wyrwicz nie zna lub nie podziela uformowanej w pierwszej połowie XVIII wieku w kręgu akademików petersburskich teorii normańskiej, opartej m.in. na przekazie Nestora. Jego wiedza o publikacjach Müllera czy Bayera musiała być więc bardzo powierzchowna. Najwyraźniej także nie podziela tradycyjnej hipotezy Macieja Stryjkowskiego, jakoby określenie Rosja miało pochodzić od ,rossieia znaczącego w ruskim języku rozproszenie". W Uwagach tę koncepcję wiąże jednak nie z wywodami Stryjkowskiego, lecz z sądem ,niektórych Moskali”. Jego zdaniem nazwy etniczne Moskali i Rossów przyniesione zostały wraz z tymi ludami z Azji. Szukając ich miejsca w przestrzeni historycznej, dowolnie interpretuje informacje i identyfikuje etnonimy występujące u starożytnych autorów. Twierdzi, iż Kapadocyjczycy, zwani przez Józefa Flawiusza „Moschici”, to właśnie protoplaści Moskali, a „w Azyi wespół z Moskalami mieszkali Rossowie od Russa jego wnuka idący"148. Uwaga ta odnosi się do zdania Józefa Flawiusza wyrażonego w księdze pierwszej Dawnych dziejów Izraela: „A Mescheńczycy wywodzący się od Mescha [Mosocha syna Jafeta JK], obecnie zwą się Kapadocejczykami"149. Wyrwicz podąża tu za opinią Bernarda Wapowskiego, którą ugruntowali następnie Marcin Bielski i Maciej Stryjkowski, a prowadzącą nawet do przekonania, że wszyscy Słowianie wywodzą się od Mosocha ${ }^{150}$.

Kolejne uwagi dotyczą drobnych nieścisłości i pomylonych faktów w narracji Lacombe'a. Wyrwicz zwraca np. uwagę, że w 1533 r. Inflanty nie były jeszcze pod polską protekcją i przypomina przy tej okazji okoliczności aktu lennego Krzyżaków inflanckich oraz o „dependencji” mistrzów inflanckich od Krzyżaków, zakończonej wykupem w 1513 r. Protestuje także przeciw myleniu „Samojedii” z Samogitią (czyli Żmudzia) i włączaniu tej ostatniej w obszar podbojów Wasyla III. Przedstawia także inną niż Lacombe wersję pokonania i ukarania Stiepana Razina oraz losów „czwartego Dymitra”. Bunt chłopsko-kozacki 1670-1671 budził żywe zainteresowanie w ówczesnej Europie, jego przebieg omawiany był obszernie m.in. w popularnym seryjnym przeglądzie najnowszych dziejów powszechnych pt. Theatrum Europaeum, które ukazywa-

${ }_{148}$ Karola Wyrwicza... Uwagi..., [w:] J. Lacombe, Historia odmian..., s. 142.

149 W świetle dzisiejszych ustaleń utożsamianie Meszkeńczyków z Kapadocyjczykami pozbawione jest jakichkolwiek podstaw - Józef Flawiusz, Dawne dzieje Izraela, cz. 1, tłum. Z. Kubiak, J. Radożycki, komentarz J. Radożycki, Warszawa 1993, s. 111.

150 J. Strzelczyk, Mity, podania i wierzenia dawnych Słowian, Poznań 2007, s. 131133. 
ło się we Frankfurcie od 1635 do 1738 roku $^{151}$. To są prawdopodobne źródła wiedzy jezuity o tym konflikcie. W drugim przypadku możemy mieć pewność, że rzekoma historia odkrycia syna Łżedymitra I w $1632 \mathrm{r}$. i zabiegów moskiewskich, które doprowadziły do wydania go i okrutnej kaźni (1653), to streszczenie bałamutnej opowieści francuskiego historyka Jeana Baptiste'a de Rocolesa (1620-1696) ${ }^{152}$. Wyrwicz powołuje się zresztą bezpośrednio na jego dzieło Les imposteurs insignes. De Rocoles usilnie szukał swego miejsca w Europie, był historiografem benedyktyńskim króla francuskiego, profesorem prawa w Paryżu, przez kilka lat w Berlinie radca i historykiem z mianowania Fryderyka Wilhelma Wielkiego Elektora, następnie mieszkał w Lejdzie. Towarzyszyły temu kilkakrotne zmiany wyznania, a na koniec życia powrócił na łono Kościoła rzymskokatolickiego, osiadł we Francji i zmarł w Tuluzie ${ }^{153}$. Jako historyk nieco dowolnie traktował źródła historyczne w poszukiwaniu sensacji i barwnych opowieści. Już Kajetan Kwiatkowski (1769-1852) w Dziejach narodu polskiego za panowania Władysława IV, króla polskiego i szwedzkiego (Warszawa 1823) zwracał uwagę na wątpliwości dotyczące relacji de Rocolesa o Dymitrze IV i podawał znacznie wiarygodniejszą wzmiankę kanclerza wielkiego litewskiego Albrechta Stanisława Radziwiłła o podobnej nieco sprawie Jana Faustyna Łuby, która mogła być źródłem nieporozumienia ${ }^{154}$. Kwiatkowski, co prawda, krytykuje za tę łatwowierność Grzegorza Kniażewicza, thumacza Lacombe’a, a więc nie dostrzega, że autorem Uwag jest Wyrwicz.

Także w sprawie relacji rosyjsko-mołdawskich w czasach Dymitra Kantemira jezuita odwołuje się do literatury francuskojęzycznej. Na stronach 154-157 kreśli cały żywot Kantemira na podstawie Vie de Demetrius Cantémir prince de Moldavie, zamieszczonego jako aneks do tłumaczenia francuskiego sławnego dzieła Kantemira o historii Porty Ot-

151 Z. Wójcik, Dzieje Rosji, Warszawa 1971, s. 165.

152 J. B. de Rocoles, Les imposteurs insignes, ou histoires de plusieurs hommes de néant, des toutes nations qui ont usurpé la qualité d'empereurs, roys et princes avec leurs portraits, Amsterdam 1696 (było także wydanie Amsterdam 1683, uzupełnione - Bruxelles 1728), s. 373-386. De Rocoles tak uwiarygadnia swą opowieść: „C'est le Sieur Bertrand de la coste Parisien ([...] que j'ay connu à Hambourg, où il estoit colonel d'artillerie) personnage de probité et de mérite qui a extraordinairement voyagé et qui a vecû en cette Cour et esté caressé extraordinairement du grand duc et qui a esté témoin oculaire de la mort de ce Demetrius, duquel je tiens cette histoire", (s. 385-386).

153 J.-M. Quérard, dz. cyt., t. 8, Paris 1836, s. 103. Nouvelle biographie générale depuis les temps les plus reculés jusqu'à nos jours, red. F. Hoefer, t. XLII, Paris 1863, szp. 472-473.

154 S. 290-291. Por. też opis tej sprawy u Franciszka Siarczyńskiego w Obrazie wieku panowania Zygmunta III, króla polskiego i szwedzkiego zawierajacym opis osób zyjacych pod jego panowaniem, t. 1, Lwów 1828, s. 115-117. 
tomańskiej ${ }^{155}$. W swych uwagach Wyrwicz uwzględnia również szereg kwestii odnoszących się do spraw polskich, np. że Piotr I nie przysłał wojska Augustowi II do zwalczania konfederacji tarnogrodzkiej. Zwraca przy tym uwagę na fakt, że wojska rosyjskie pozostawały w Rzeczypospolitej aż do pokoju w Nystad, ,lubo do wyprowadzenia tego wojska tak król, jako stany Rzeczypospolitej cara nakłonić usiłowały"156. Polski aspekt jest także bardzo istotny w najważniejszej, ostatniej (nr XX) i najobszerniej omówionej kwestii, a mianowicie stosunku dworów europejskich do przyjęcia przez Piotra I tytułu cesarskiego. Sprawa uznania przez Europę tytułu nadanego przez senat z duchowieństwem i szlachta „Panu swemu nad obszernemi krainami panującemu i najpotężniejszemu w Europie monarsze" zajmuje prawie połowę objętości uwag Wyrwicza (s. 158-172), skłania go zresztą do krytycznego osądu gruntowności francuskich autorów: „Dziejopisowie francuscy nigdy naganiani nie byli o zbytnią pilność i dokładne historii pisanie oraz uważne tych rzeczy, które piszą i przywodzą roztrzaśnienie. Dziś jeszcze szkodliwszy naukom biorą zwyczaj, wiele pisać, nie starając się dobrze pisać, dawnym księgom nowy kształt dowcipnie dawać, gładkością stylu uwdzięczać, przypuszczając nawet do pism swych omyłki. $Z$ wywodu tego, który tu położę każdy pozna, czy J. P. Lacombe dobrze rzecz roztrząsnąwszy i nie tylko z cudzoziemskich gabinetów, lecz z domowego wersalskiego wiadomości zasięgnąwszy napisał: że dwory cudzoziemskie nie ociagaty się etc." ${ }^{157}$. Wyrwicz rozpoczyna od ogólnych wywodów na temat suwerenności, która nie jest związana z wielkością władztwa (przykład San Marino). Posiłkując się autorytetem Jeana Bodina, podkreśla, że monarchów charakteryzuje pełna niezależność, a „karzeł jest równie człowiekiem jak olbrzym". Szczegółowo omawia trudności związane z właściwym rozumieniem i włączeniem w sferę europejskich pojęć prawnomiędzynarodowych tytulatury władców rosyjskich. Zwraca także uwagę na polityczną stronę zagadnienia, zwłaszcza istotną dla Rzeczypospolitej, bowiem miano „władcy Wszechrusi” oznaczało roszczenia terytorialne wobec części obszaru polsko-litewskiego państwa. Przypomina, że Rzeczpospolita długo odmawiała tytułu „cara” władcom moskiewskim: „Roku 1650 poselstwo rosyjskie wysłane było do Warszawy dla powinszowania Janowi Kazimierzowi wstapienia na tron i potwierdzenia traktatów. Po-

155 Dymitr Kantemir, Histoire de l'Empire Ottoman, avec des notes, thum. De Jonquières, t. 4, Paris 1743, s. 467-488 (na podstawie wyciagu z rękopisu Kantemira przetłumaczonego na angielski przez N. Tindala i wydanego w Londynie w 1734 r.).

156 Karola Wyrwicza... Uwagi..., [w:] J. Lacombe, Historia odmian..., s. 158.

157 Tamże. 
słowie dopraszali się takich honorów, które się wyrządzają posłom głów koronowanych, a mianowicie paradnej królewskiej karety. Co wszystko było im odmówiono, a po tym i sami, gdy z zuchwałością swoje pretensje popierali bez uszanowania majestatu polskiego, pod straż byli dani, z której za przybyciem gońca moskiewskiego i powrotem z Moskwy polskiego uwolnieni, na pokój wieczny (ten był wkrótce po tym zerwany) zgodzili się i przymierze nowe podpisali" ${ }^{158}$. Przedstawia okoliczności stopniowej zmiany stanowiska dworów europejskich z podkreśleniem, iż było to możliwe tylko dzięki przyjęciu zasady, że ,nowa cesarsko-moskiewska godność nad dawne w Europie nie będzie wynosiła się trony, ale przy tych zostanie honorach, których przodkowie Piotra W. używali" ${ }^{159}$. Wyrwicz omawia kolejne perturbacje dyplomatyczne i rozważa drobne niekiedy niuanse tej sprawy. Dochodzi do czasów Katarzyny II i jej deklaracji z 1762 r., iż tytuł cesarski nie zmieni w niczym ,ustaw obrządkowych, abo ceremoniału między dworami zwyczajnego". Zgoda dworu francuskiego i hiszpańskiego wyrażona została pod warunkiem, że tytuł cesarski nie ma „w najmniejszej rzeczy wpadać do rangi i porządku przodkowania między potencjami ustanowionego", w przeciwnym razie nastapi powrót „do dawnego stylu i tytułu”. Kwintesencją rozważań jest sprawa uznania tytulatury cesarskiej przez Rzeczpospolitą z podkreśleniem związanych z tym gwarancji nienaruszalności terytorium kraju. „Warunki pełnomocnych ministrów swych umacniając, Katarzyna II listem dyplomatycznym ręką swoją własną podpisanym i pieczęcią cesarską obwarowanym wszystko to potwierdziła, co stanom Rzeczypospolitej było obiecano i od stanów życzono" (7/18 czerwca 1764 r.) $)^{160}$. Wtedy dopiero naród zgromadzony na „szczęśliwą Najjaśniejszego Stanisława Augusta” elekcję „monarchom rosyjskim tytuł cesarski przyznał” - stwierdza Wyrwicz w ostatnim zdaniu swych Uwag nad historiq odmian $w$ państwie rosyjskim przez Jakuba Lacombe po francusku napisanej.

Uważny ich czytelnik dostrzeże także publikacje i drobne pisma polityczne ,po państwie niemieckim rozrzucane”, które zostały odnotowane w zestawieniu bibliograficznym do dziejów Rosji. Zauważy także odnotowywanie zmian w tytulaturze ,ruskich” władców w ich wykazie chronologicznym, a ponadto rozważania nad uzurpacją elektorów brandenburskich w kwestii tytułu króla pruskiego, uznanego przez Rzeczpospolitą dopiero w roku $1764^{161}$. O znaczeniu tych spraw dla Wyrwicza

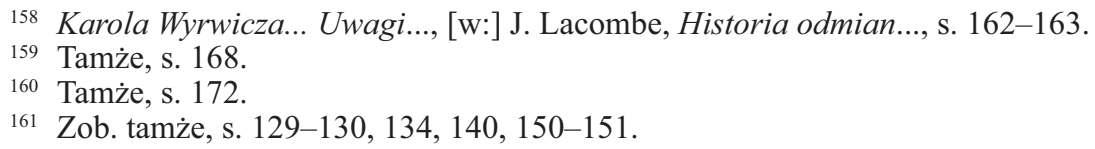


świadczą rozbudowane przypisy w oprotestowanej przez ambasadę rosyjską Geografii czasów teraźniejszych. Przypisy te - zdaniem Mieczysława Fleszara - łamią kanony metody opisowej, a autor ,,jak gdyby poza ustalonym schematem starał się przedstawić swój punkt widzenia [...]"162. Wśród tych najobszerniejszych jest oczywiście rozbudowana dygresja o zasadach następstwa na tronie rosyjskim od czasów Piotra Wielkiego i o kwestii uznania tytułu imperatorskiego przez państwa europejskie ${ }^{163}$. W szerszym kontekście trzeba tu odwołać się do charakterystycznych dla ówczesnego naszego piśmiennictwa historycznego kategorycznych sprzeciwów wobec wszelkich, nawet średniowiecznych ,zakusów” na suwerenność Polski, jak np. w sprawie niezależności monarchii piastowskiej od Cesarstwa ${ }^{164}$. Mieści się to w nurcie „obrony” sarmackiego świata przed pomówieniami, oskarżeniami i fałszywymi sądami cudzoziemców zazdrosnych o nasze wolności. Wątki tego rodzaju są szczególnie widoczne w publikacjach i wypowiedziach osób związanych z kręgiem Biblioteki Załuskich ${ }^{165}$.

Program wydawniczy tego środowiska ze szczególną atencją odnosił się do dawnych tekstów i dokumentów istotnych dla tradycji kultury szlacheckiej Rzeczypospolitej. Ich ujawnienie lub przypomnienie miało służyć rewitalizacji tej kultury, ale także refleksji nad postawami i zasadami, które dawały krajowi niegdyś mocarstwową pozycję, zarazem gwarantując jego narodowi politycznemu prawa i wolności w duchu republikańskim. Dlatego w przedmowie do edycji „rymów wszytkich” Jana Kochanowskiego Bohomolec stwierdzał z pewną emfazą: „Po długim lat przeciagu otworzyliśmy oczy. Powróciliśmy znowu do owych czystych źródeł, z których prawdziwe nauki wypływają. Poznawamy już cenę i szacunek dawnych naszych autorów: i któremi niedawno gardziliśmy, tych doskonałości teraz dziwujemy się. Mędrsi jesteśmy, ale już po szkodzie, ponieważ wiele ich pism wielce szacownych tak wyginęło, iż ledwie ich ślady w innych autorach znajdujemy. Nic nam teraz nie

${ }_{162}$ M. Fleszar, Zarys historii geografii ekonomicznej w Polsce do 1939 r., Warszawa 1962, s. 20.

163 K. Wyrwicz, Geografii czasów teraźniejszych..., t. 1, s. 287-288.

164 Szerzej o tym zob. J. Kurkowski, Z dziejów polskiego edytorstwa..., s. 130-131. Także Konarski we wstępie do tomu pierwszego Volumina Legum (Leges, statuta, constitutiones, privilegia Regni Poloniae, Magni Ducatus Lithuaniae, Warszawa 1733) polemizował z niewymienionymi z nazwiska autorami niemieckimi, którzy skracali dzieje parlamentaryzmu polskiego i kwestionowali ciagłość tradycji prawa od najdawniejszych czasów.

${ }^{165}$ Zob. J. Kurkowski, Historycy jezuiccy w kręu magnackich mecenasów (XVIII w.), [w:] Wkład jezuitów do nauki i kultury w Rzeczypospolitej Obojga Narodów i pod zaborami, pod red. I. Stasiewicz-Jasiukowej, Kraków - Warszawa 2004, s. 508. 
zostaje, jako od podobnej ratować zguby te przynajmniej pisma, które szczęściem jakimści do naszych czasów dotrwały"166. Studiowanie dawnych tekstów i dokumentów źródłowych miało służyć aktualnym i ważnym celom: to „czyste źródło” wzorców i przykładów, swoisty program reform, sposób analizy rzeczywistości i porządkowania o niej wiedzy, instrument edukacji publicznej, a nawet forma obrony uprawnień międzynarodowych państwa i integralności jego terytorium. Zasadniczo „źródła i fakty powinny mówić same za siebie”, lecz właściwemu ich rozumieniu pomagał niekiedy dobór tekstu, specjalny komentarz edytorski, addenda. Jak daleko mogły sięgać takie erudycyjne zamiary wobec mechanizmów realnego świata, pokazuje przykład J. A. Jabłonowskiego, jednego z ważnych mecenasów, promotorów, moderatorów i wykonawców tego programu wydawniczego. Omawiając w 1773 r. dokończenie swego dzieła o stosunkach dziejowych (a właściwie dziejowej bliskości) Polski i Francji, uzależniał umowę od wydarzeń wojny rosyjsko-tureckiej. Pisat: „,cet livre me deviendra inutile, si 1 a p a i x [podkr. JK] se fait"167. Wierzył chyba naprawdę, że taka publikacja może zmienić bieg polityki międzynarodowej i odwrócić decyzje rozbiorowe. Przedwczesne zawarcie pokoju te rachuby przekreślało (faktem jest, że po traktacie w Küczük-Kajnardży druk nie nastapił).

Zainteresowanie dziejami potężnego sąsiada $\mathrm{w}$ polskim piśmiennictwie XVIII stulecia ujawnia się wraz z dążeniem do poszerzenia oglądu świata i wraz ze startem programu edytorskiego Biblioteki, a więc jeszcze w czasach saskich (i nie widać w tej kwestii jakiejś istotnej cezury przed pierwszym rozbiorem). Zgodnie z wymogami erudycyjnego modelu dziejopisarstwa pojawiły się niebawem pytania o źródła, o bibliografię przedmiotowa, chronologię, a wreszcie faktografię. Osiagnięcia w tej dziedzinie okazały się jednak dość skromne, bowiem punktem odniesienia i źródłem inspiracji oraz wiedzy była głównie literatura zachodnioeuropejska, w szczególności francuskojęzyczna. Wyrwicz i Kniażewicz nie starają się wykorzystać swojej przewagi wynikającej z sąsiedzkiej (choć często konfliktowej) bliskości z Rosja, z orientacji we wspólnej ze wschodnią Słowiańszczyzną części zbioru wydarzeń historycznych i bez porównania lepszej niż we Francji znajomości wtopionego w przestrzeń kulturową Rzeczypospolitej „,ruskiego” świata - języka, prawosławia, obyczajów itp.

166 Jana Kochanowskiego rymy wszytkie w jedno zebrane prócz tych, które wolniejszemi żartami uczciwych czytelnikow odrażały, wyd. F. Bohomolec, Warszawa 1767. Zob. B. Nadolski, Epoka stanisławowska wobec polskiego renesansu, „Pamiętnik Literacki", 33:1936, nr 1/4, s. 446-447.

${ }_{167}$ Kraków, Bibl. Czartoryskich, rps 1163, s. 771. Szerzej na ten temat J. Kurkowski, Józef Aleksander Jabłonowski i historiografia, w druku. 
Wolą korzystać z dorobku niekontrowersyjnych kompilatorów, popularnych przedstawicieli „kronikarskiego” nurtu francuskiej literatury historycznej - powielać lub adaptować ich ujęcia, schematy i oceny, nawet ze świadomością (jak np. Wyrwicz) pewnych strukturalnych wad dziejopisarstwa znad Sekwany. Z drugiej zaś strony w analizowanym piśmiennictwie można dostrzec też wpływ ugruntowanego w Rzeczypospolitej przynajmniej od XVII stulecia negatywnego stereotypu „Moskala”. Do rangi symbolu urasta jednak to, że w $1773 \mathrm{r}$. w Warszawie przedrukowano po francusku dzieło André-Guillaume'a Contanta D'Orville (1730-1805) Les fastes du Royaume de Pologne et de la Russie ${ }^{168}$. Korelacja opisu dziejów Rosji i Polski jest tu oczywista. Drugi tom owego kronikarskiego ich przeglądu poświęcony został Histoire de la Russie. Contant podąża śladem Lacombe'a, jego narracja toczy się według podobnego schematu chronologicznego, koncentruje się też wokół panowania Piotra I. Epokowe przemiany wiąże jak poprzednik (i jak Wolter) z siłą woli i konsekwencją tego władcy, zaś zbrodnie (następca tronu Aleksy) usprawiedliwia bezkompromisowym programem reform ${ }^{169}$. Późniejszy o dekadę tekst Contanta omawia także elekcję Stanisława Augusta, rzekomo wolną - wojska rosyjskie wkroczyć miały tylko dla przywrócenia porządku. Temu celowi służyło także uprowadzenie polskich senatorów - jedyny sposób na tryumf sprawiedliwości. W uwagach końcowych odnoszących się do schyłku roku 1768 Katarzyna II jawi się jako władczyni o wyjątkowej mocy sprawczej, pracowitości i wytrzymałości: prowadzi wojnę z Turcja, podtrzymuje na tronie Stanisława Augusta, dba o porządek i sprawiedliwość w Rzeczypospolitej oraz o uszczęśliwienie ludu ${ }^{170}$.

Na takim „frankofońskim” tle zupełnie wyjątkowo rysuje się projekt, po którym pozostała, niestety, jedynie lakoniczna wzmianka w archiwum Stanisława Augusta. Oto na podstawie inwentarza Jana Albertrandiego wiemy o przygotowanym przez wspomnianego już Antoniego Kossakowskiego (Moliwdę, o którym powstała powieść Andrzeja Żuławskiego pod takim tytułem) Opisaniu państwa moskiewskiego [...] z słowiańskiego na polski

168 Pierwsze wydanie miało miejsce w Paryżu w 1769 r. Zob. też Bibliografia polska.., t. XIV, Kraków 1896, s. 388. Inne dzieło Contanta przetłumaczył na polski pijar Joachim Antoni Karwowski (1736-1821) pt. Opisanie naturalne, historyczne i polityczne różnych krajów świata, Warszawa 1774. Opisu Rosji tam nie ma. Joseph-Marie Quérard określa Contanta następująco: ,auteur dramatique, romancier et compilateur”, dz. cyt., t. 2, Paris 1828, s. 276. W Nouvelle biographie générale zwraca się uwagę na „obfitość" jego twórczości, z czego niektóre rzeczy zasługują na uwagę, t. XI, Paris 1855 , szp. 642-643.

169 I. Hanslik, dz. cyt., s. 183-184.

170 Tamże, s. 185; A.-G. Contant D’Orville, Les fastes du Royaume de Pologne et de la Russie, t. 2, Paris 1769, s. 285. 
język przethumaczonym ${ }^{171}$. Według inwentarzowej informacji thumaczenie miałoby się ukazać w 1768 r., ale nic nie wskazuje na istnienie takiego druku. Widocznie w otoczeniu Stanisława Augusta w czasach największych złudzeń wobec polityki Katarzyny II pojawił się pomysł sięgnięcia bezpośrednio do piśmiennictwa rosyjskiego dla kompetentnego i na pewno przyjaznego zaprezentowania kraju, w czym standardowo zawierał się wówczas przegląd jego dziejów. Ustalenie, która rosyjska publikacja została przetłumaczona (streszczona) ${ }^{172}$, byłoby niezmiernie interesujace.

Warto przy tej okazji zauważyć, że wszystkie omawiane przedsięwzięcia wydawnicze dotyczące dziejów Rosji (także te niezrealizowane) mają charakter de facto publiczny, a nawet państwowy - jak w przypadku działań króla Stanisława Augusta. Żadnej innej problematyki historycznej jednak nie moderowała wówczas tak wyraźnie cenzura, niekiedy nawet o znamionach cenzury prewencyjnej (vide casus tomu 2 i 3 Kodeksu Dogiela).

\section{Streszczenie}

\section{Dzieje Rosji w piśmiennictwie doby stanisławowskiej. Część I: do pierwszego rozbioru}

Celem badawczym jest charakterystyka obrazu dziejów Rosji w polskim piśmiennictwie epoki stanisławowskiej (z uwzględnieniem niezrealizowanych ostatecznie inicjatyw wydawniczych). Artykuł obejmuje okres do I rozbioru polsko-litewskiego państwa (1772).

Zainteresowanie dziejami potężnego sąsiada, wpływającego $\mathrm{w}$ istotny sposób na bieg wydarzeń w Rzeczpospolitej, ujawnia się już w czasach panowania Augusta III wraz z dążeniem do poszerzenia oglądu świata i startem opartego na wzorcach historiografii erudycyjnej programu edytorskiego Biblioteki Załuskich (otwartej dla publiczności w 1747 r.). Te wzorce objaśniają zainteresowanie kwestią źródeł do historii Rosji, bibliografii przedmiotowej, chronologii, faktografii. Osiagnięcia okazują się jednak dość skromne, bowiem podstawę wiedzy o historii Rosji stanowiła głównie popularna literatura francuskojęzyczna. Autorzy polscy nie starają się wykorzystać swej lepszej znajomości wtopionego w przestrzeń kulturową Rzeczypospolitej „ruskiego” świata (języka, prawosławia, obyczajów). Wolą korzystać z dorobku francuskich kompilatorów, powielać lub adaptować ich ujęcia, schematy i oceny, nawet ze świadomością strukturalnych wad tego dziejopisarstwa.

171 P. Bańkowski, Archiwum Stanisława Augusta, Warszawa 1958, s. 32, 304.

172 Może zresztą niejedna? 
W analizowanym piśmiennictwie można dostrzec też wpływ ugruntowanego w Rzeczypospolitej przynajmniej od XVII w. negatywnego stereotypu „Moskala”.

Słowa kluczowe: piśmiennictwo epoki stanisławowskiej - historiografia polska XVIII w. - obraz dziejów Rosji - oddziaływanie literatury francuskiej - stereotyp Rosjanina - program wydawniczy Biblioteki Załuskich.

\section{Summary}

\section{History of Russia in the Polish literature during the times of King Stanisław. Part I: To the First Partition (1772)}

The author undertakes to characterise the image of Russia in the Polish literature of the era of King Stanisław Poniatowski (including editorial projects, which actually never came to fruition). The article brings the story to the First Partition of the Polish-Lithuanian Commonwealth (1772).

Interest in the history of the mighty neighbour, who markedly influenced the course of political events in the Commonwealth, can be noticed as early as during the reign of King Augustus III. It accompanied the tendency to widen the scope of the view of the surrounding world brought in by the erudite historiography in the editorial programme of the Załuski Library (opened to the public in 1747). This in turn explains the interest in primary sources, bibliography, chronology, and the history of Russia itself. However, the results of these interests seem modest. The majority of the works that appeared were based on popular French literature. The Polish authors made little effort to use their superior knowledge of the Ruthenian world amalgamated with the fabric of the Commonwealth (language, Eastern Christianity, customs). Instead, they preferred to keep to the French compilations, copy or adapt their views, patterns, and evaluations, even if they were conscious of the structural fallacies of such historiography.

The other thing evident in the analysed writings is the presence of the negative stereotype of the "Muscovite". This stereotype appeared in the Commonwealth not later than during the XVII century.

Key words: Polish literature of the reign of King Stanisław Poniatowski - Polish historiography (18th c.) - presentations of the history of Russia - influence of French culture - stereotype of a Russian in literature - editorial programme of the Załuski Library. 